\title{
En glemt skat: Miranda Bødtkers tegninger af arkæologiske tekstiler
}

\begin{abstract}
Over many years, illustrator Miranda Bødtker (1896-1996) carried out drawings for botanists, zoologists and archaeologists at Bergen Museum, the University of Bergen. After her death, thousands of drawings were discovered in her estate. Among them were numerous unpublished drawings of archaeological textiles from five sites. Bødtker's illustrations show that although several scholars have studied the textiles, none had seen them all. This applies in particular to textiles from two Viking Age burials, Grønhaug and Dale, both of which comprise remains of figured tapestries that are hardly mentioned in archaeological literature. Grønhaug, and a boat from Halsnøy also offer several types of textiles related to the maritime world. The paper presents Bødtker's drawings and discusses how they compare with published descriptions of those textiles, with drawings of textiles from the Oseberg burial, and to what degree this form of documentation meets current scientific demands.
\end{abstract}

\section{Tegninger som videnskabelig dokumentation}

Tegning har været en central form for dokumentation af arkæologisk materiale, ofte foretrukket fremfor fotografier, men er kostbart og derfor i dag ofte erstattet af digitale løsninger. Tegninger er også brugt til at dokumentere tekstiler. Under udgravningen af Oseberggraven malede Ola Geelmuyden akvareller af udvalgte stykker, og siden udførte Sofie Krafft og Mary Storm en lang række tegninger af tekstilerne fra Oseberg (Christensen og Nockert, red. 2006; Vedeler 2019). Disse tegningerne viser mange detaljer der ikke længere kan ses på de originale tekstiler. Som det fremgår af Marianne Vedelers nyudgivne bog om billedvævningerne fra Oseberg (Vedeler 2019), repræsenterer de derfor en værdifuld kilde til dette enestående materiale, og gør det muligt at se det med nye øjne. I denne artikel præsenteres en række tegninger af vestnorske jernalder- og vikingetidstekstiler, udført af Miranda Bødtker (1896-1996). Disse tegninger er aldrig blevet publiceret, men de samme fund er til forskellige tider blevet beskrevet af en række arkæologer og tekstilkyndige. Det gør det muligt at sammenligne hvad Bødtkers øjne så og tegnede, og hvad de forskellige forskere så og formulerede i ord, og blot i enkelte tilfælde dokumenterede med fotos. Som det vil fremgå, er der både ligheder og forskelle mellem Bødtkers tegninger og de hovedsagelig skriftlige beskrivelser af tekstilerne, og tegningerne stiller dermed en række spørgsmål og åbner nye problemstillinger. I nogle tilfælde har tegner og forsker set forskellige

Kontakt: Lise Bender Jørgensen, E-post: lise.bender@ntnu.no

${ }^{1}$ NTNU - Institutt for historiske og klassiske studier.

${ }^{2}$ De naturhistoriske samlinger, Universitetet i Bergen 
aspekter ved tekstilerne, $i$ andre afviger observationerne klart; enkelte tegninger viser tekstiler som ikke er dokumenteret andetsteds. Hvad skyldes disse diskrepanser, hvilke nye oplysninger giver tegningerne os om tekstilerne, og hvad fortæller de os om tegninger som videnskabelig dokumentation?

\section{En tegner og hendes vark}

Miranda Bødtker var født og opvokset i Bergen (figur 1). Hun fik sin uddannelse ved Bergens Kunsthaandverksskole samt Tekniska Skolan i Stockholm. Derefter blev hun i 1920 ansat som mønstertegner ved Kunsthaandverksskolen i Bergen, en stilling hun havde indtil 1966, hvor hun gik af med pension (Moe, red. 2006). Bødtker udviklede en sjælden interesse for detaljer i naturen, hovedsagelig blomster og dyr, som hun brugte til å finde nye motiver til brug i forbindelse med kunsthåndverk, især tekstil. Et af hendes vigtigste arbejdsredskaber var en lille håndlup. Som en del af sit arbejde (og måske delvis som hobby) dokumenterede hun gamle senge- og vægtæpper (åklcer), vægmalerier, brugskunst og meget andet. Som lærer i mønstertegning fremstillede hun sit eget undervisningsmateriale, hvor hun benyttede den indsigt hun havde erhvervet sig om naturens små detaljer. Bødtker var i mange år en skattet frivillig medarbejder ved Bergens Museum (UiB). Hendes skarpe blik for de små detaljer var af stor betydning for det dokumentationsarbejde som fandt sted indenfor arkæologi, zoologi og især botanik (Korsmo 2006). Her blev en væsentlig del av hendes produktion til i kontinuerligt samarbejde med det videnskabelige miljø. I bogværket Norsk flora stod hun for illustrationerne i sort/hvidt (Nordhagen 1940; Bødtker 1970). Hun udførte også talrige tegninger af arkæologiske fund, deriblandt tekstiler.

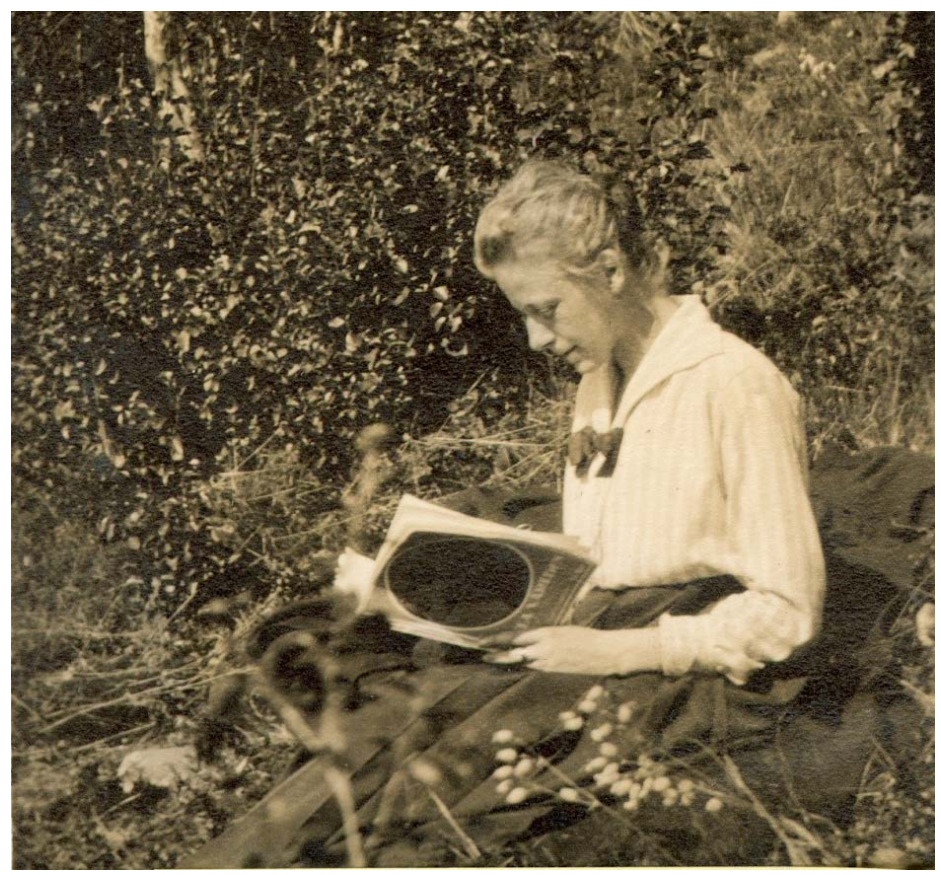

Figur 1: Miranda

Bødtker.

Foto: Bergen

Museum. 
I de 30 år som pensionist var Botanisk museum (UiB) Bødtkers faste kontakt med videnskaben, og der foreligger en lang række videnskabelige arbejder hvor hendes omhyggelige stregtegninger er viktige bidrag (se liste i Moe, red. 2006:62-63). Hun overlevede imidlertid mange af sine videnskabelige kolleger og arbejdsgivere, med det resultat at mange av hendes illustrationer blev glemt, især de ældste. Da hun ikke havde nogen arvinger, arvede miljøet omkring museet hele boet da hun gik bort. Overraskelsen var stor da hendes efterladenskaber blev pakket ud, og det viste sig at bare en håndfuld av hendes illustrationer (heraf næsten 10000 akvareller) var kendt. I dag ligger det aller meste af materialet ved Konserveringsavdelingen ved Universitetsmuseet i Bergen. En udstilling baseret på en lille del av hendes arbejder blev vist i 2006.

\section{Tegningerne af arkæologiske tekstiler}

Bødtker kom tidlig i kontakt med det arkæologiske miljø ved Bergens Museum, først Haakon Shetelig og siden Johannes Bøe, og blev inviteret til at tegne og dokumentere arkæologiske fund. De første vi kender til, er en samling tuschtegninger samt nogle få akvareller af tekstilfragmenter fundet ved udgravninger på Vestlandet og i Rogaland. Det blev efterhånden mange fund, og Bødtker blev tydeligvis fascineret af de gamle tekstilrester. Det drejer sig om tegninger af tekstiler fra følgende fund: Grønhaug, Bø i Torvestad, Karmøy, Rogaland (B 5758); Øvre Tofte, Halsnøy, Kvinnherad, Hordaland (B 5406); Dale, Ytre Holmedal, Sunnfjord, Sogn og Fjordane (B 3106b); Døsen, Sogn \& Fjordane (B 6091), og Blindheim, Vigra, Møre og Romsdal (B 8628). Så vidt vides er tegningene ikke tidligere publiseret, med to undtagelser (Moe, red. 2006:37 og 40).

Tekstilerne er kort omtalt i Bergens Museums tilvekster og i nogle tilfælde i artikler og studier vedrørende fundet de tilhørte (Shetelig 1902, 1903, 1912). Flere er beskrevet af Johan Hiorth (1908), i Bjørn Hougens studier om norske jernalder- og vikingetidstekstiler (Hougen 1935; Christensen og Nockert red. 2006:75), og i Lise Bender Jørgensens katalog over norske oldtidstekstiler (Bender Jørgensen 1986). Beskrivelserne i disse arbejder er kortfattede og stort set uden dokumentation i form af billeder. Nogle af tekstilerne blev nærmere undersøgt, dokumenteret ved fotografier og publiceret i en serie arbejder af Bente Magnus (1982, 1983, 1988), Margareta Nockert (1991) og Inger Raknes Pedersen (1982, 1983, 1988), og fotos af enkelte tekstiler indgår i Arnfrid Opedals arbejde om skibsgrave på Avaldsnes (Opedal 1998:72). Bødtkers tegninger blev udført længe inden disse arbejder, og er en unik kilde - også til hvordan det letforgængelige materiale har tålt mange års opbevaring i museumsmagasiner.

Grønhaug, Bø, Torvestad, Karmøy, Rogaland. B 5758.

Grønhaug på Karmøy blev udgravet af Haakon Shetelig i 1902. Fundene blev ført til Bergens Museum hvor de fik museumsnummer B 5758 (Shetelig 1902, 1912). Højen viste sig at indeholde en 15 meter lang båd, hvori en person var gravlagt. Graven var plyndret, og gravgodset lå hulter til bulter. Det omfattede bl.a. en mængde dun og fjer, samt større stykker af tekstiler. Shetelig tolkede dette som at den døde har været anbragt på en dundyne, omtrent midt i båden. Dette fik ham til at datere graven til vikingetiden, da han anså dundynen for en nyhed i vikingetiden (Shetelig 1912:223). Dateringen er siden revideret i flere omgange. Bjørn Myhre (1980) placerede fundet i merovingertid, mens Arnfrid Opedal 
(1998) støttede Sheteligs datering til vikingetid. Senest har dendrodateringer vist at båden er bygget ca. 780, og at gravlæggelsen skete mellem 790 og 795 (Bonde og Stylegar 2009:162). Dermed placeres graven i overgangen mellem de to perioder.

Shetelig beskrev tekstilerne som "Adskillige større og mindre stykker af tøier. Et meget fint, som tildels endnu har en frisk rødbrun farve, er antagelig af en kloedning. Desuden er der et par noget grovere stykker og et enkelt meget grovt og tykt, muligens af baadens seil" (Shetelig 1902:10). Et par år senere blev tekstilerne beskrevet af Johan Hiorth (1908:18). Han fandt at de bestod af fire forskellige typer stof: A) Et meget fint, toskaftet uldtøj med mørk, rødbrun farve. Med henvisning til en frk. H. Christensen angiver Hiorth at der "ved vavningen er benyttet en meget grov sked og meget stram rending, samt løs, men taet slået vaft". B) Et stykke grovere og lysere end foregaaende, yderst tyndt. C) Et stykke groft, firskaftet uldtøj. D) Et stykke firskaftet hamp, antagelig af et sejl samt "et stykke firlagt snøre av totvundet hamp". Hiorths beskrivelser gengives af Shetelig (1912:223), nu med tilføjelsen "vel snarere av baatens telt" til forslaget om at D) er rester af skibets sejl.

Tekstilerne blev næste gang undersøgt sommeren 1982 af Lise Bender Jørgensen, der fandt følgende: 1) Tekstilfragmenter, største stykke 9 x $7 \mathrm{~cm}$. Repsvævet, z/z-spundet garn, $35 / 10$ tråde pr. $\mathrm{cm}^{2}$; 2) Flere større tekstilfragmenter, største stykke 9,5 x 7,5 cm, hhv. $10 \mathrm{x}$ $9 \mathrm{~cm}$. Repsvævet med brocheret mønster (tilsyneladende billedvævning). Garnet S2z/S2z + mønstertråd, også S2z, 28/12 tråde pr. $\mathrm{cm}^{2}+$ brochering. 3) 20 x $15 \mathrm{~cm}$ stort tekstilfragment. Repsvævet, z/z-spundet garn, 25/6 tråde pr. $\mathrm{cm}^{2}$. 4) Flere større tekstilfragmenter, fundet sammen med større masser af dun/fjer. Formentlig rester af dyne/pude. Sammensyning. 2/2 kipervævet, z/z-spundet garn, 24/7 tråde pr. cm² (Bender Jørgensen 1986:257, katalog N:IV:4). Bender Jørgensens repsvævninger 1) og 3) svarer til Hiorths A og B; hans grove, fireskaftede uldtøj (C) er formentlig Bender Jørgensens 4). Derimod mangler Hiorths fireskaftede hamp med tilhørende snøre i Bender Jørgensens notater, mens Bender Jørgensens observationer af billedvævning (3) mangler hos Hiorth.

Miranda Bødtkers tegninger af Grønhaug-tekstilerne omfatter ikke mindre end 22 plancher. De er nummereret 1-16 (planche11-13 med undernumre a), b) og i et tilfælde c) hvortil kommer to unummererede). Tekstilerne fordeler sig på mindst 10 forskellige typer. Det drejer sig om flere forskellige lærredsbindinger i uld, deriblandt et fint repsvævet stof, muligvis med rester af broderier; yderligere en repsvævning; en halvpanama; en lærredsvævning med brochering/billedvæv; en anden med 'frit mønster', og en lærredsvævning med grove uldtråde der kan repræsentere rester af et stof med ilagt flos. Endnu en lærredsvævning kan være de som Hiorth har bestemt som kipervævet hamp. Dertil kommer et antal kipervævninger: grovere, balancerede, på hhv. 7/8 og 11/13 tråde pr cm², og ubalancerede, på 6/11 og 9/19 tråde pr. cm², førstnævnte med syninger, samt småfragmenter af fin krystalkiper af Birka-type (for definition se Bender Jørgensen 1986:169-170). Til dette skal lægges rester af kalfatring, samt en snor. Kun dele af disse er omfattet af Johan Hiorths og Lise Bender Jørgensens beskrivelser. Det betyder, at Miranda Bødtkers tegninger rummer hidtil ukendte, og derfor overordentlig værdifulde, tekstiler fra Grønhaug, der kan bidrage til at kaste nyt lys over skibsgravens indretning.

Planche1 viser ifølge Bødtkers håndskrevne følgetekst "Brudstykker av et meget tykt stoff. Regelmoessige partier hvor renningen er helt synlig. Nr. 1, 2, 3, 4, 5 dele av stoffet. Nr. $62 / 1$ størrelse. Nr. 7 rekonstruert skjematisk, samt ulltrå, renning og islett venstrespunnet." Bødtkers tegninger og beskrivelse af dette stof svarer til dels til Bender Jørgensens type 2, 


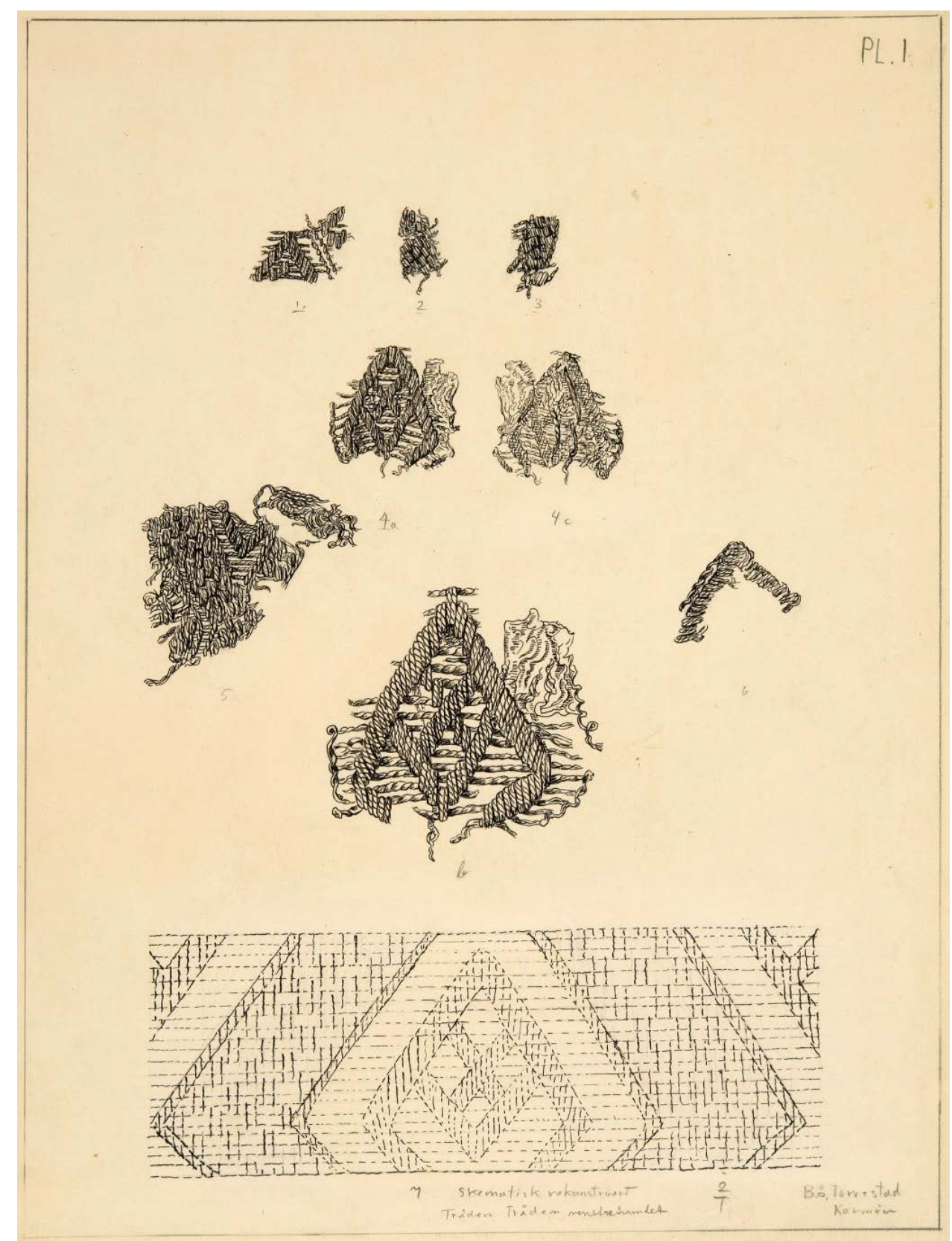

Planche 1: Grønhaug, Bø, Torvestad, Rogaland. Brudstykker af meget tykt stof, Nr. 1-5. Nr. 6: dobbelt størrelse; Nr. 7: stoffet rekonstrueret. Tegninger: Miranda Bødtker. 
men da sidstnævnte, med 28/12 tråde pr. $\mathrm{cm}^{2}$, langtfra kan passe til beskrivelsen som 'meget tykt', er det sandsynligt at Bender Jørgensen ikke har set tekstilresterne på Planche1a. Noget tilsvarende gælder efter alt at dømme Hiorth.

To unummererede plancher, her betegnet $1 \mathrm{~b}$ og $1 \mathrm{c}$, viser på den første fragmenterne Nr. 1a, 2a, 3 (i 1:1), Nr. 1b og 2b (i 2:1); Nr. 4: renningstråd x5, og Nr. 5 fire tråder sammentvunnet, garnprøver, på den anden 1 . Stoffet 1:1 og 2. en skematisk rekonstruktion. Toskaft med dobbelt trå till islett. Teksten på begge siger "Utydelig stoff", og "Bø, Torvestad, Karmøen". Teksten til planche 1 svarer ikke overens med indholdet af de to unummererede plancher (1b og 1c), og der kan derfor meget vel mangle både en planche og en billedtekst. Dette understreges af at tekst og tegninger stemmer overens for plancherne 2-16. Det, som den første af de unummererede plancher viser, er tre fragmenter af et tilsyneladende lærredsvævet stof med kraftigt, S-tvundet garn i det ene trådsystem (formentlig trenden) og et væsentligt tyndere garn i det andet trådsystem. Desuden en prøve af trendtråden (Nr. 4), som ser svagt s-spundet ud; den sidste tegning, 5: fire tråde sammentvundet, viser blot to tråde tvundet om hverandre. Bødtker har forsigtigt angivet materialet som ull?. Den anden unummererede planche viser et lille fragment i halvpanama, hvilket også fremgår af forstørrelsen. Her foreligger ingen kommentarer til materialet. Ingen af disse to stoffer svarer til de der er beskrevet af Bender Jørgensen, men kan evt. jævnføres med Hiorths type a eller b.

Planche 2 viser 3 fragmenter samt en forstørrelse af et repsvævet stof i højrespundet (z-spundet) garn, og angivelse af systing, enten broderi eller en søm. Forstørrelsen viser 6 x 28 tråde $\mathrm{pr} \mathrm{cm}^{2}$. Dette stof kan sandsynligvis identificeres med Bender Jørgensens type 3), og enten Hiorths a eller b.

Planche 3 viser 3 eksempler på lærredsvævet uldstof med forstørrelser af samme. De to første angives som højrespundne (z), det tredje som venstrespundet (s). De tre tegninger er ganske forskellige og repræsenterer formentlig 3 forskellige stykker stof. Nr. 1 er en balanceret lærredsvævning hvor hver anden trendråd er tykkere; der er omkring 10/12 tråde pr. $\mathrm{cm}^{2}$. Nr. 2 er en tæt sammenslået reps med 2/10 tråde pr. $\mathrm{cm}^{2} ;$ Nr. 3 er også en reps, her gengivet som trendreps; trådtal ikke målbart. Sidstnævnte svarer kvalitetsmæssigt til Bender Jørgensens type 1 og 3, men garnets spinderetning stemmer ikke. Dermed kan ingen af de tre tegninger identificeres med stoffer registreret af Bender Jørgensen. Da Hiorth ikke omtaler spinderetning, kan det ikke afgøres om nogen af de tre tegninger viser Hiorths type a eller b.

Planche 4 viser fire fragmenter diagonalkiper, det ene med fastsiddende dun, samt en forstørrelse af stoffet; garnet angives højrespundet (z). Trådtal omkring 11/13 tråde pr. $\mathrm{cm}^{2}$. Bortset fra trådtallet svarer dette overens med Bender Jørgensens type 4), der har 24/7 tråde pr. $\mathrm{cm}^{2}$, men kan også være Hiorths type c.

Planche 5 viser 2 prøver på fint repsvævet stof med forstørrelser; garnet højrespundet (z). De stammer sandsynligvis fra samme stof som er afbildet på planche2.

Planche 6 viser groft uldgarn i forbindelse med et tyndere, men dog groft toskaftet stof. Garnet er venstrespundet (s). Der er her muligvis tale om udekorerede dele af Bender Jørgensens type 2, repsvævning i S-tvundet garn med brochering/billedvævning. En alternativ tolkning kan være rester af et stof med ilagt flos, hvad man i dag ville kalde en rya. Sådanne tekstiler er kendt fra en række arkæologiske fund, hvoraf det tidligste er en kappe fra Trindhøj, en af de danske egekister fra bronzealderen (Broholm og Hald 1940:27-29). Fra vikingetiden kendes lignende tekstiler fra Birka (Geijer 1938:20-22), og flere lokaliteter 


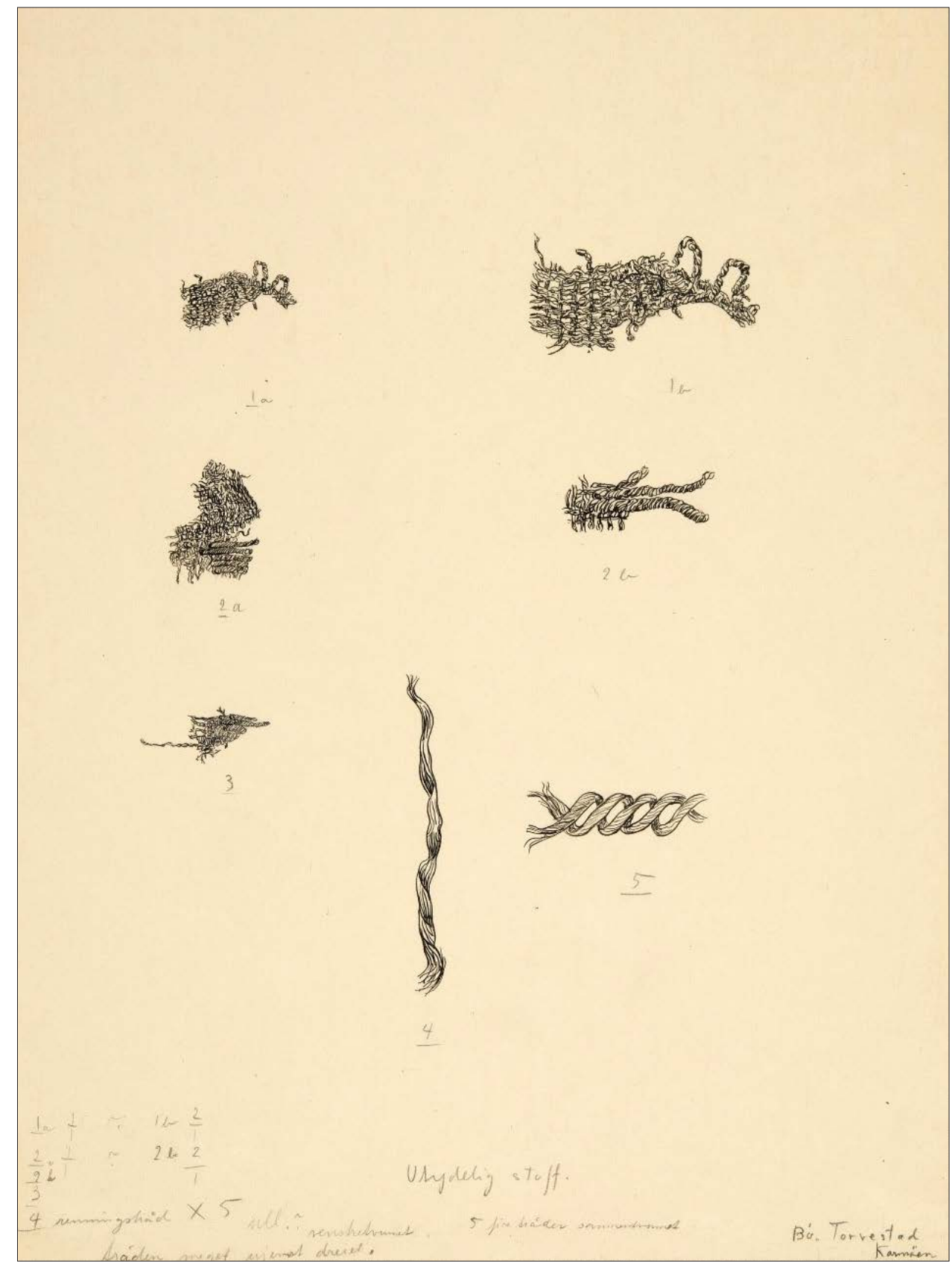

Planche 1b: Grønhaug, Bø, Torvestad, Rogaland. Utydeligt stof, Nr. 1-3. Nr. $1 b$ og 2b: dobbelt størrelse. Nr. 4: trendtråd; Nr. 5: sammentvundne tråde. Tegninger: Miranda Bødtker. 


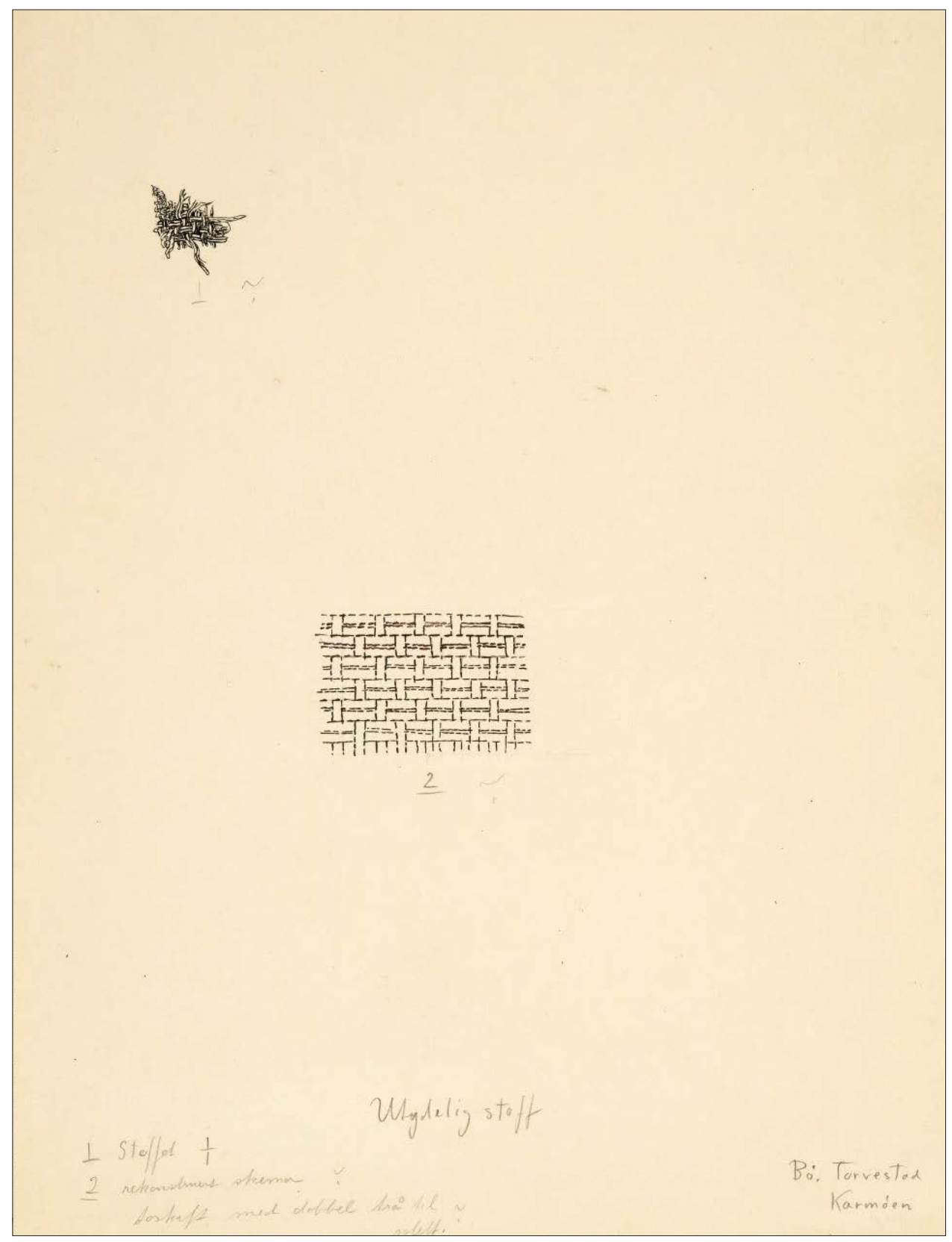

Planche 1c: Grønhaug, Bø, Torvestad, Rogaland. Utydeligt stof. Nr. 2: stoffet rekonstrueret. Tegninger: Miranda Bødtker. 


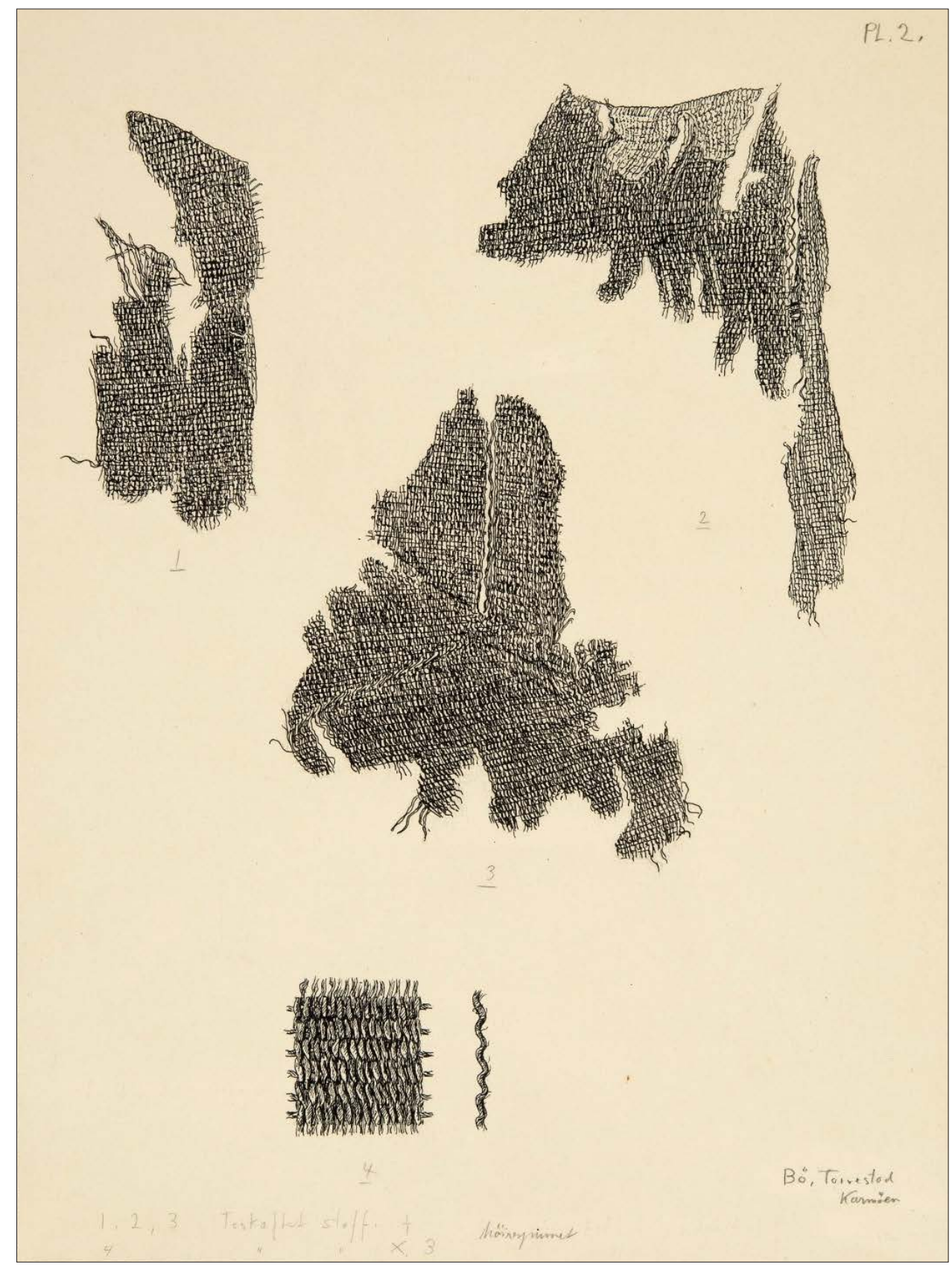

Planche 2: Grønhaug, Bø, Torvestad, Rogaland. Toskaftet stof af højrespundet garn, Nr. 1-3. Nr. 4: tredobbelt størrelse. Tegninger: Miranda Bødtker. 


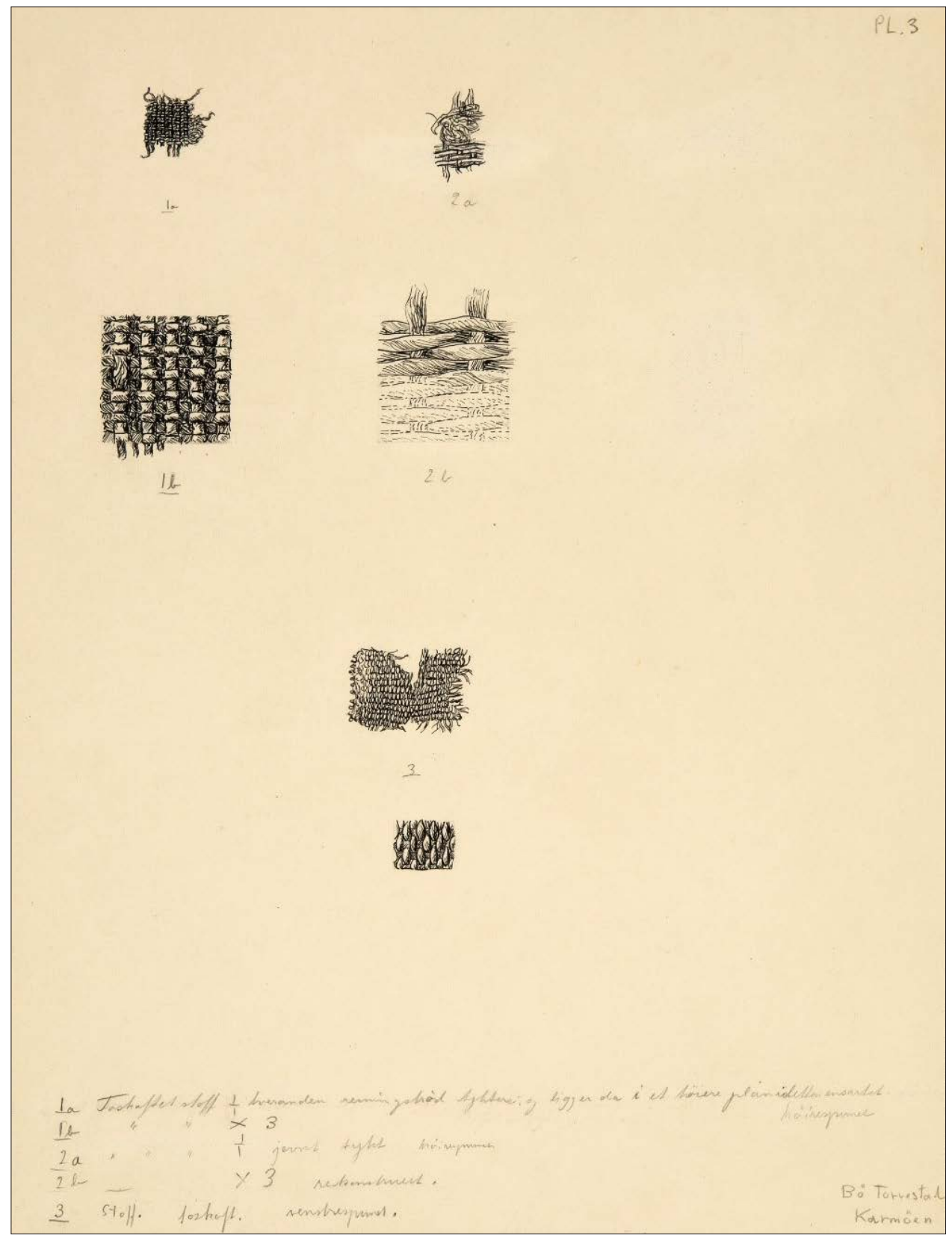

Planche 3: Grønhaug, Bø, Torvestad, Rogaland. Nr. 1a: Toskaftet stof, hveranden trendtråd tykkere. Nr. 1b: tredobbelt størrelse. Nr. 2a: jcevnt tykt højrespundet. Nr. 2b: stoffet rekonstrueret. Nr. 3: Toskaftet stof af venstrespundet garn. Tegninger: Miranda Bødtker. 


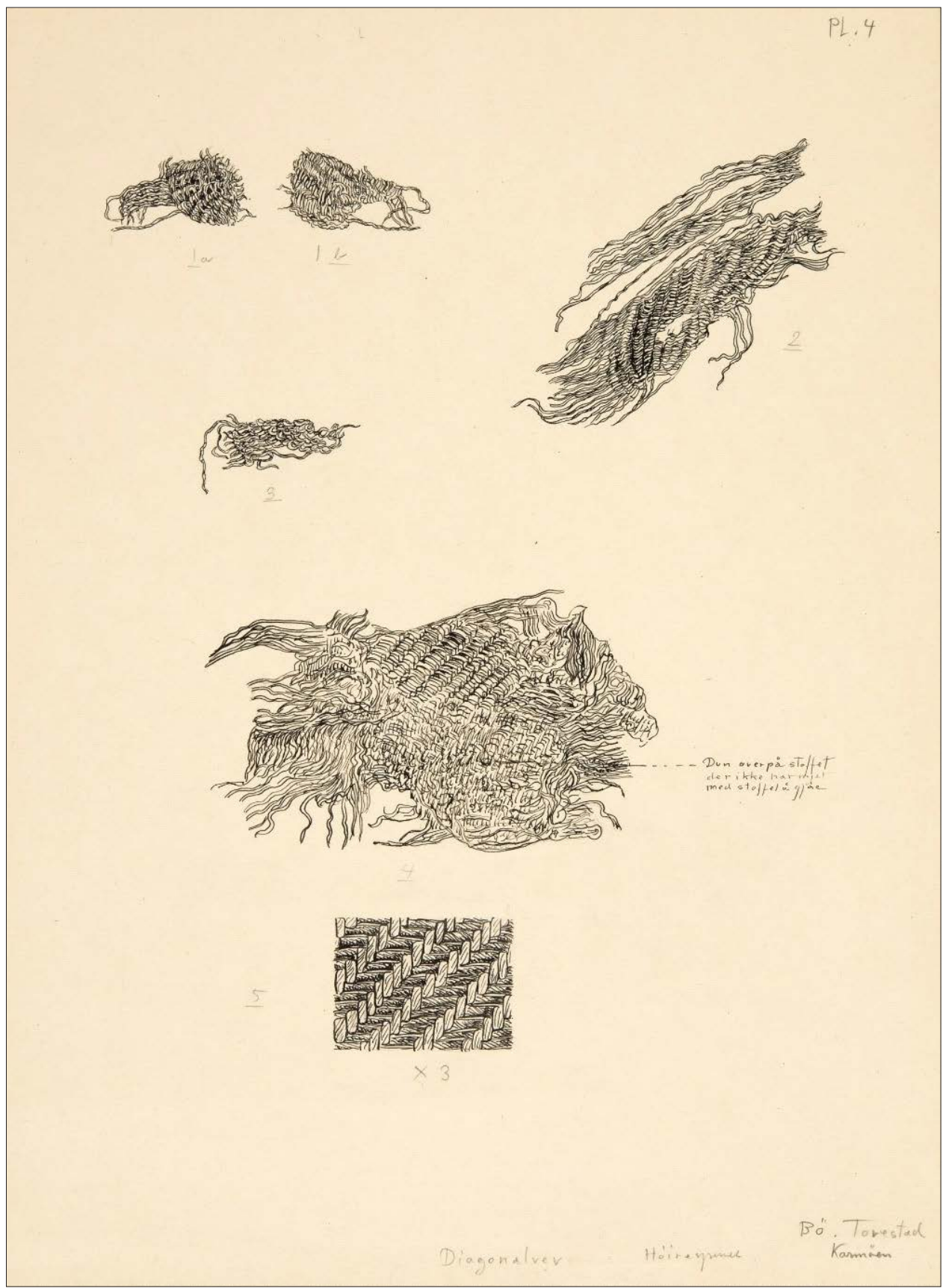

Planche 4: Grønhaug, Bø, Torvestad, Rogaland. Diagonalvovet stof af højrespundet garn, Nr.1-4. Nr. 5: tredobbelt størrelse. Tegninger: Miranda Bødtker. 


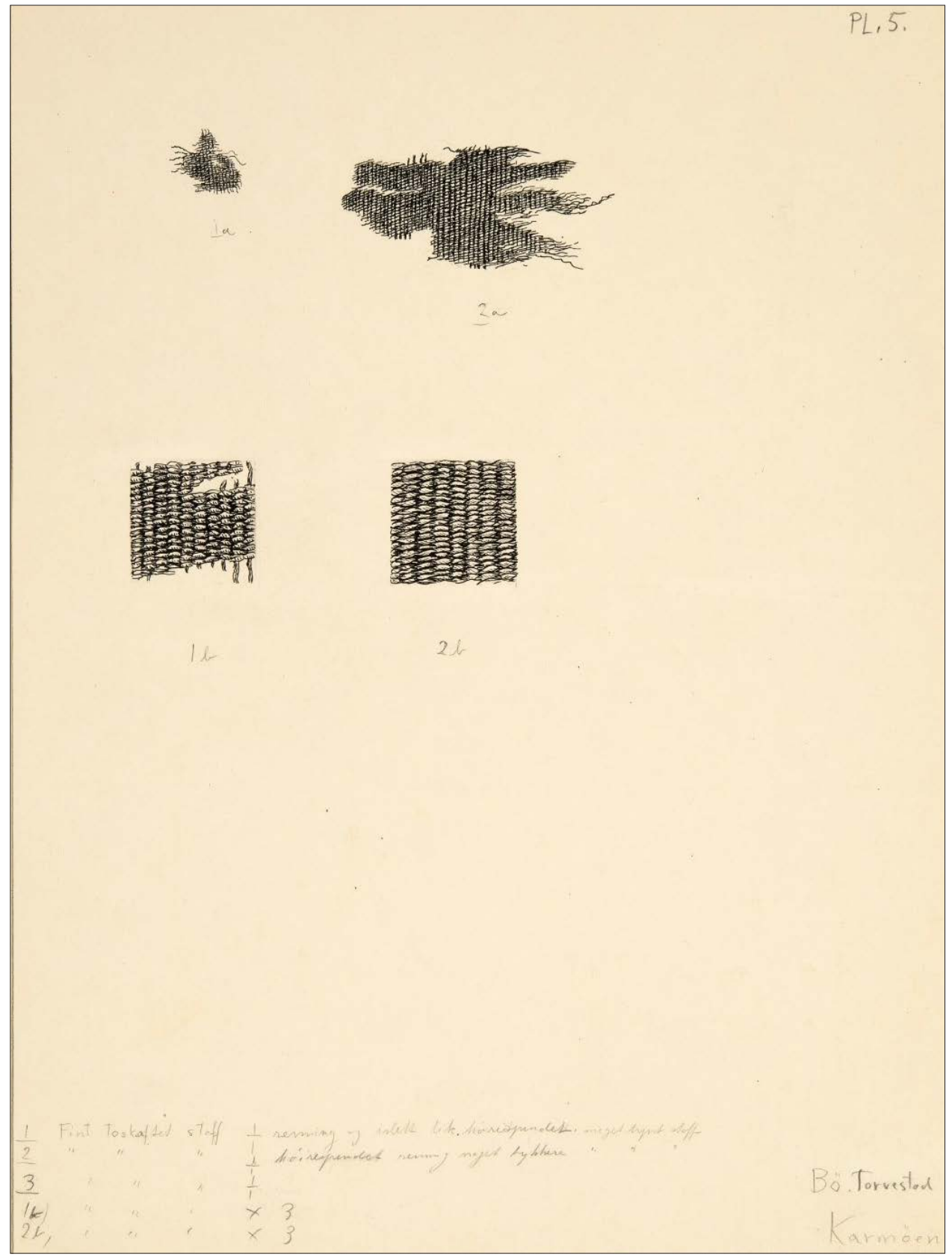

Planche 5: Grønhaug, Bø, Torvestad, Rogaland. Fint toskaftet stof, Nr. 1-3. Nr. 1 b og 2b: tredobbelt størrelse. Tegninger: Miranda Bødtker. 


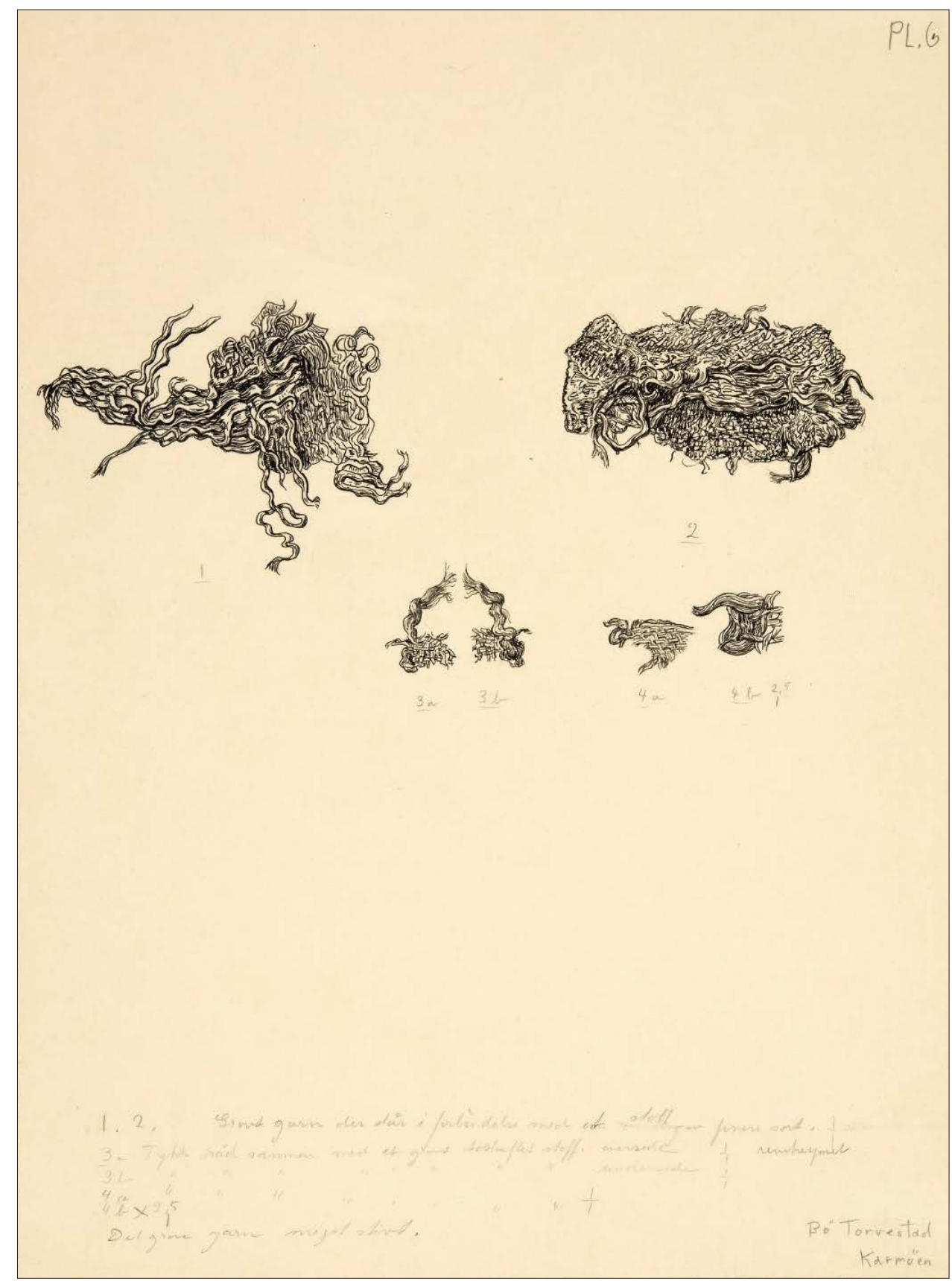

Planche 6: Grønhaug, Bø, Torvestad, Rogaland. Nr. 1 og 2: groft garn der står i forbindelse med finere stof. Nr. 3: Tyk tråd sammen med groft toskaftet stof. Nr. $4 a$ og 4b: 2,5x størrelse. Det grove garn meget stift. Tegninger: Miranda Bødtker. 


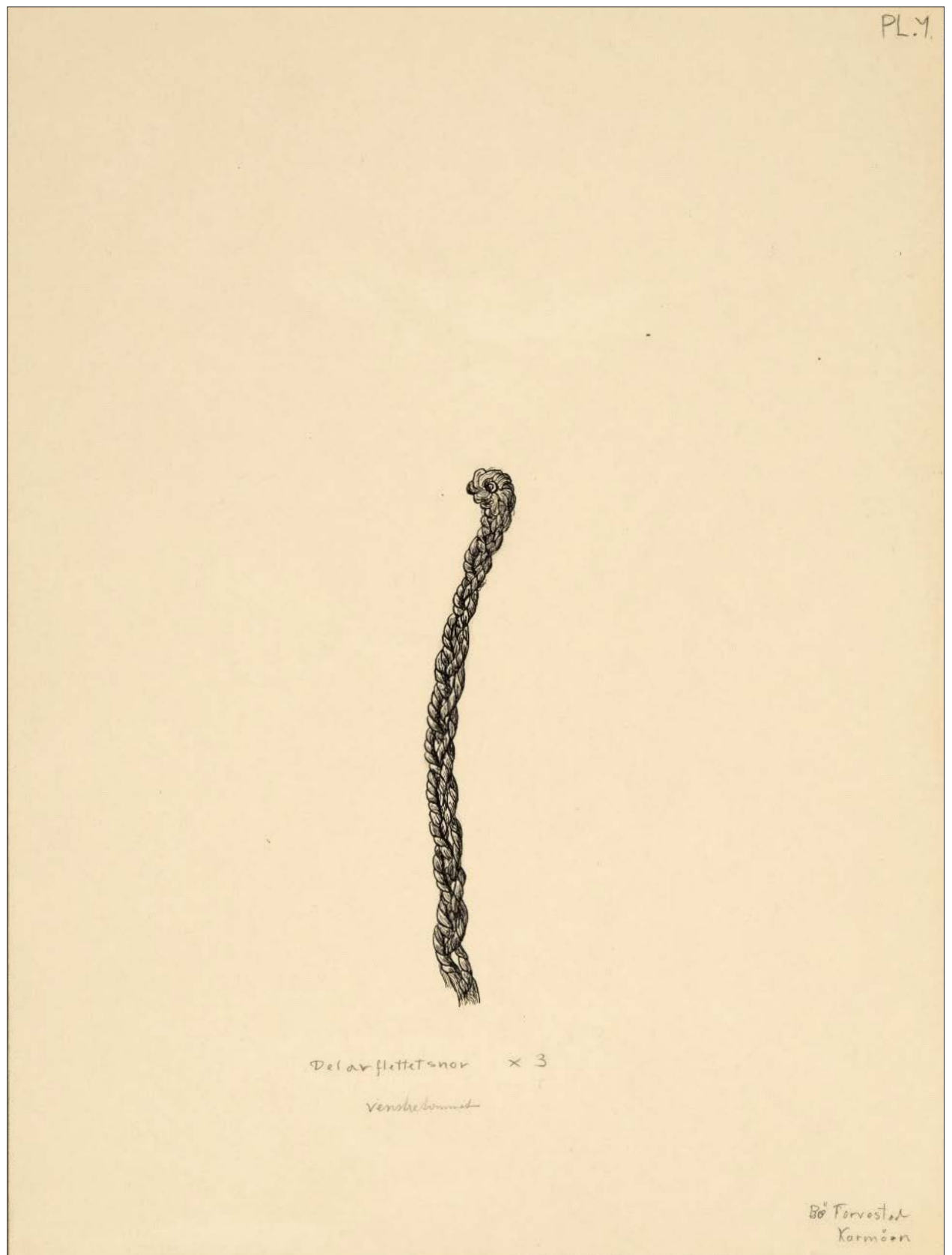

Planche 7: Grønhaug, Bø, Torvestad, Rogaland. Del afflettet snor. Tredobbelt størrelse. Venstrespundet. Tegning: Miranda Bødtker. 
i Storbritannien (Wincott Heckett 1992:162). Et velbevaret eksemplar, den såkaldte St. Brigids kappe i katedralen i Brugge, stammer formentlig fra det 11. århundrede (Wincott Heckett 1992:161-162). Denne type kapper tjente som varmt overtøj, og kunne ligeledes bruges til at sove i. I norsk kystkultur kendes sådanne varme flos-tæpper under navnet båtryer (Kjellmo 1996).

Planche 7 viser en snor, flettet af venstretvundet (S-snoet) tråd. Denne kan eventuelt være identisk med Hiorts firslåede hampesnøre, men er treslået, ikke firslået. Bødtker angiver ingen oplysninger om hvilken fibertype der er tale om.

Planche 8 viser prøver af et tykt diagonalvævet $2 / 2$ kiper, brunlig-gulbrunt, i højrespundet (z) garn, Nr. 4 i 3 x forstørrelse. Beregnet ud fra forstørrelsen har stoffet ca. 7/8 tråde pr. $\mathrm{cm}^{2}$. Dette er sandsynligvis Hiorths type c, men er ikke repræsenteret i Bender Jørgensens typer. Det kan stamme fra samme stof som kipervævningen på planche 5 .

Planche 9 er ligeledes et tykt uldent stof i diagonalkiper med luv, dvs. opbørstet på undersiden, i højrespundet garn. Trådtal ifølge forstørrelsen ca. 9/19 tråde pr. cm². Dette kan være en prøve af Bender Jørgensens type 4, evt. Hiorths type c.

Planche 10 viser fragmenter af et mønstret stof beskrevet af Bødtker som brochert spjellvev i højrespundet garn (z). Forstørrelsen viser en fin repsvævet grund; både den og mønsteret minder meget om et fint uldtøj med 'frit' mønster fra en sen vikingetids grav i Hvilehøj, Randers Ydervang i Støvring herred, Danmark (NM C 4280a), som er beskrevet af Margrethe Hald (Hald 1950:116-117, 1980:111-119 (kat. No. 77, figs. 109-110). Dette stof er $i k k e$ beskrevet hverken af Johan Hiorth eller Lise Bender Jørgensen.

Planche 11-13 udgør en gruppe. Planche 11 (a, 11b indsat) viser brosjeret spjellvev i venstrespundet garn (s) set fra begge sider. Planche 12a viser også et stykke brosjert spjellvev med en udtegning af mønstret, Planche $12 \mathrm{~b}$ og c yderligere hver 2 fragmenter og rekonstruktioner af disse. Planche $13 \mathrm{a}$ og b viser videre fragmenter af samme stof. Disse stoffer svarer til Bender Jørgensens type 2), fint repsvævet uldstof i S-tvundet garn, 28/12 tråde pr. $\mathrm{cm}^{2}$, med brochering/billedvævning. Dele af det, især planche 13, har nære ligheder til dele af billedvævningerne fra Oseberg (se f.eks. Bjørn Hougens bidrag i Christensen og Nockert, red. 2006:61-63, og Vedeler 2019:36). Hougen var opmærksom på tekstilerne fra Grønhaug. Han nævner at flere af dem kan bestemmes som billedvævninger, og anfører at de udviser det karakteristiske grundmønster 1, enkelte motivrester samt den karakteristiske slyngede kontur som på svensk kaldes snärjing (Christensen og Nockert, red. 2006:75).

Bødtker beskriver disse stykker som spjellvev, og tegningerne antyder at der har været tale om smalle, eller relativt smalle, bånd. Spørgsmålet er dog om de reelt er vævet på spjældvæv, dvs. en båndvæv, eller om de er udført på en væv specielt beregnet på billedvævninger. Bevarede billedvævninger fra vikingetid og tidlig middelalder som bonaderne fra Överhogdal er mellem 24 og $37 \mathrm{~cm}$ brede (Oscarsson 2010). Hougen og Vedeler beskriver billedvævningerne fra Oseberg som mellem 16 og $23 \mathrm{~cm}$ høje, inklusive de påsyede brikvævede borter (Christensen og Nockert, red. 2006:17, 32; Vedeler 2019:33), og diskuterer om den velbevarede væveramme der blev fundet i Oseberg-graven kan have været brugt til at fremstille dem. De konkluderer begge at det er fuldt muligt men at det ikke kan afgøres med sikkerhed (Christensen og Nockert, red. 2006:84-85; Vedeler 2019:33).

Billedvævningerne på planche 11-13 adskiller sig fra de mønstrede tekstiler afbildet på planche 1; men som kagerne af billedvævninger fra Oseberg viser, var disse ofte sammensat 


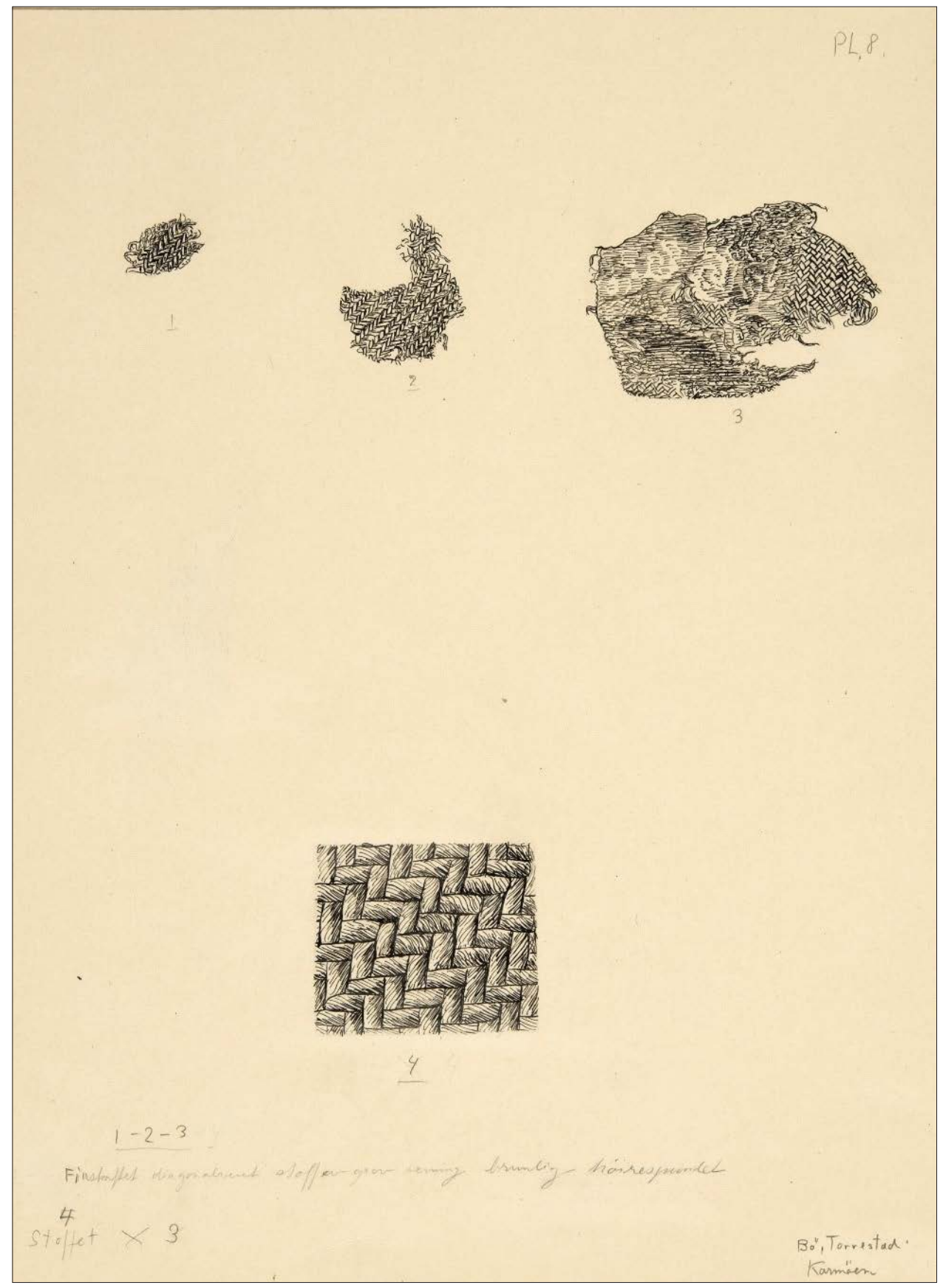

Planche 8: Grønhaug, Bø, Torvestad, Rogaland. Firskaftet diagonalvaevet stof af grov trend, Nr. 1-3. Brunligt, højrespundet. Nr. 4: tredobbelt størrelse. Tegninger: Miranda Bødtker. 


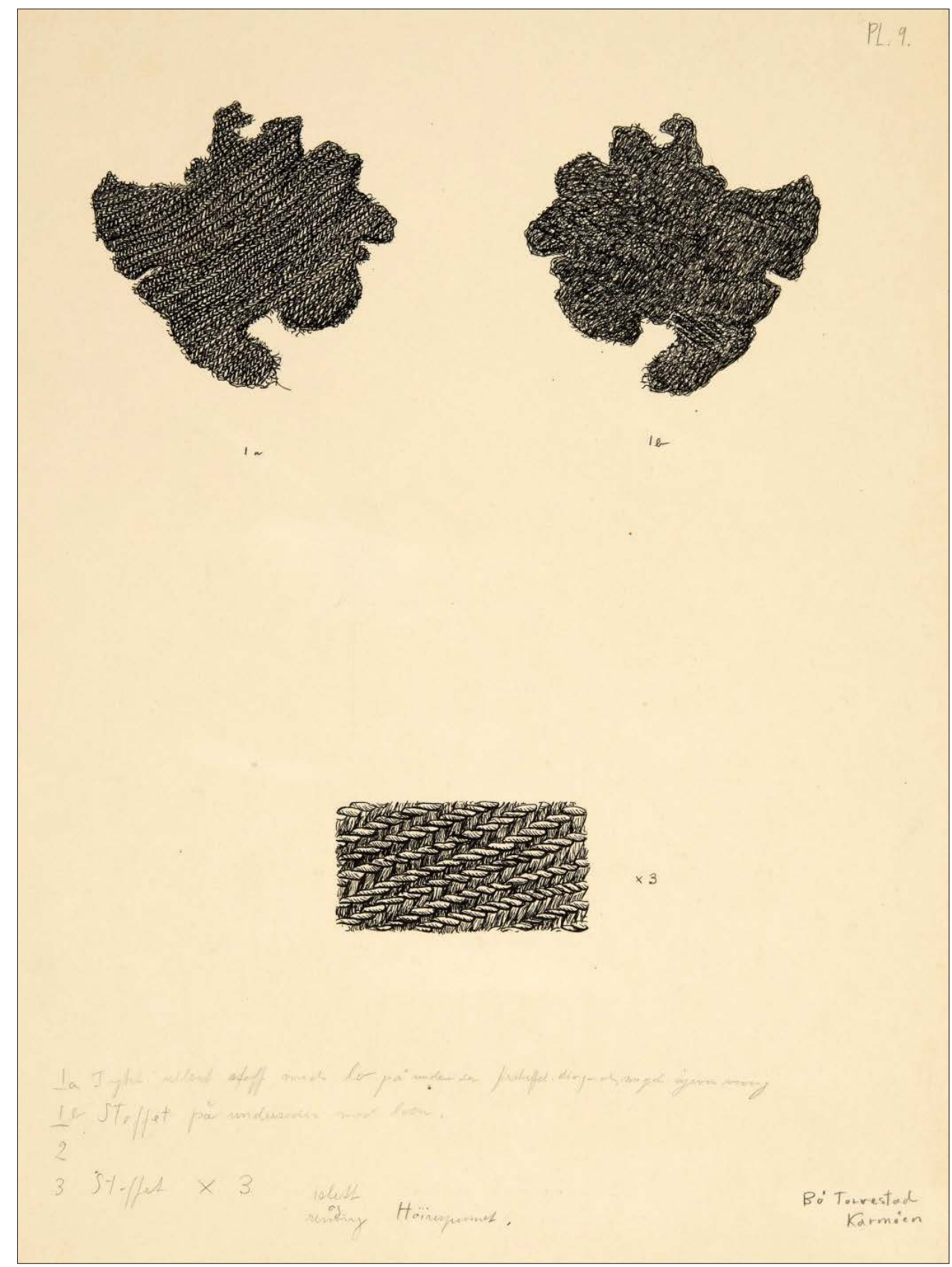

Planche 9: Grønhaug, Bø, Torvestad, Rogaland. Nr. 1a: Tykt uldent stof med luv på undersiden. Firskaftet diagonalvavet stof, meget ujovnt vavet. Nr. 1b: stoffet på undersiden med luven. Nederst: Tredobbelt størrelse. Islet og trend højrespundet. Tegninger: Miranda Bødtker. 


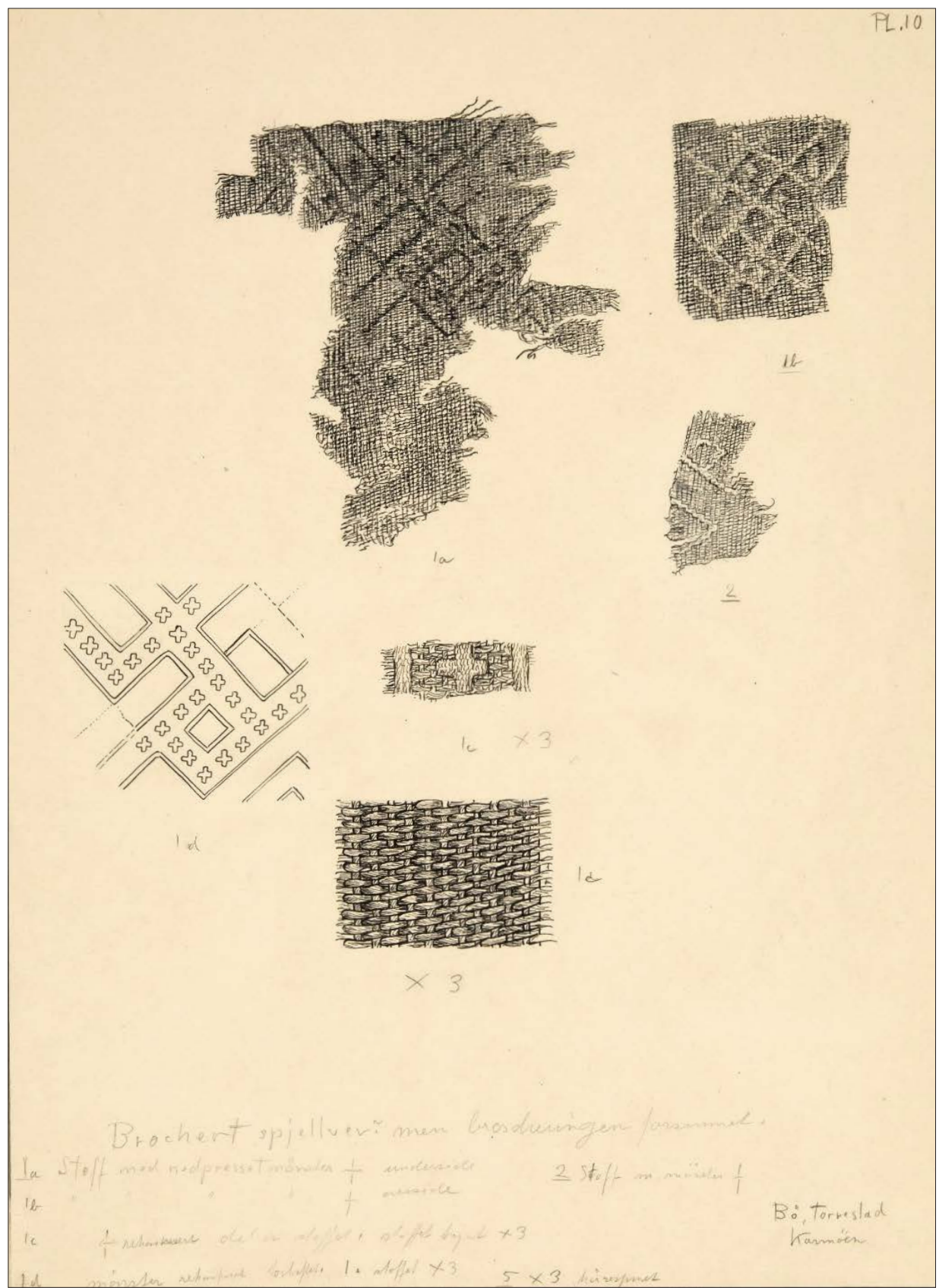

Planche 10: Grønhaug, Bø, Torvestad, Rogaland. Brocheret spjceldvcev med forsvundne mønstertråde. Nr. la og b: stof med nedpresset mønster, over- og underside. Nr. 1c: rekonstreret del af stoffet, tredobbelt størrelse. Nr. 1d: rekonstrueret mønster, tredobbelt størrelse. Nr. 2: Stof med mønster.- Højrespundet. Tegninger: Miranda Bødtker. 


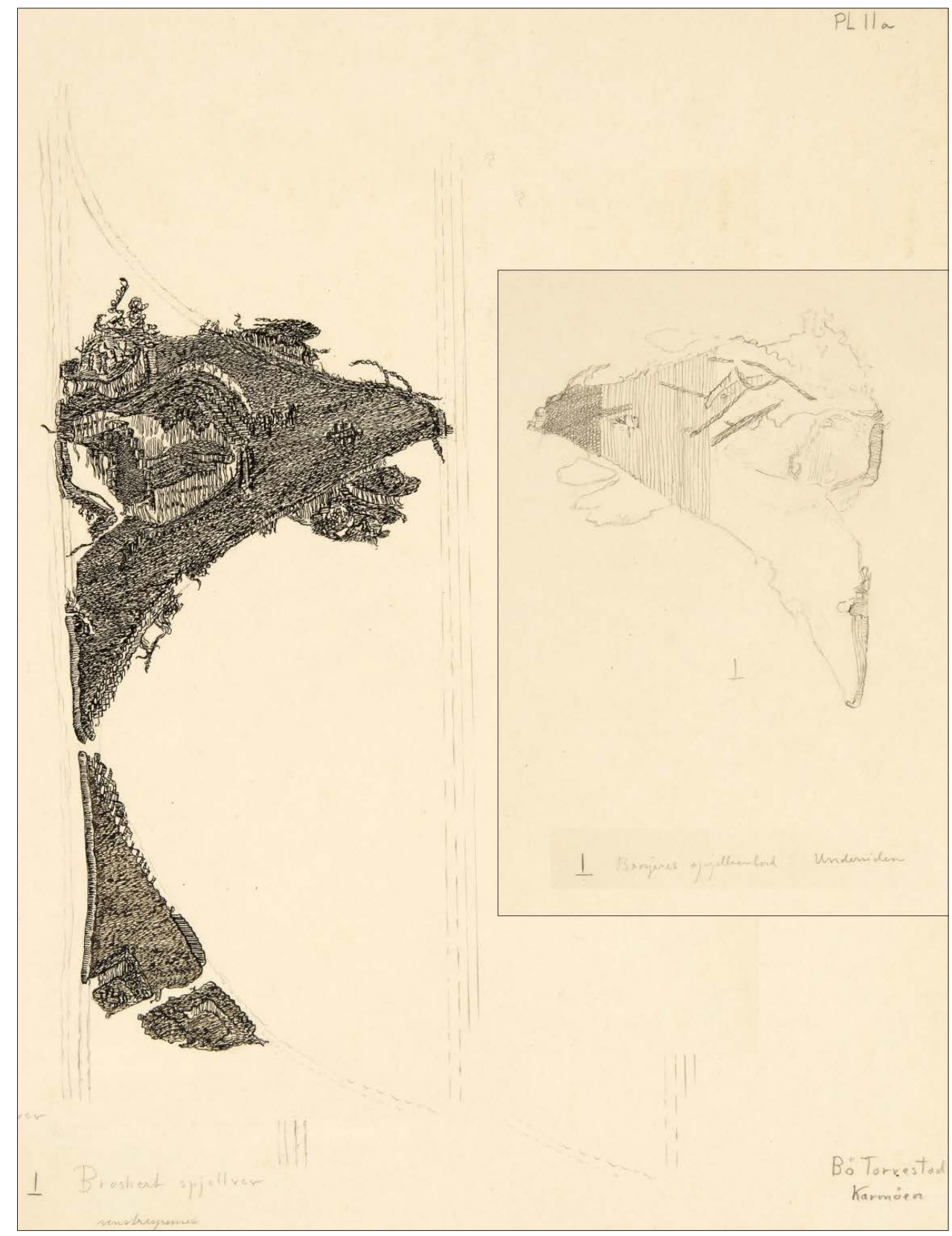

Planche 11: Grønhaug, Bø, Torvestad, Rogaland. Brocheret spjceldvaev, venstrespundet. Indsat: Oprindelig planche11b, undersiden af samme stof. Tegninger: Miranda Bødtker. 


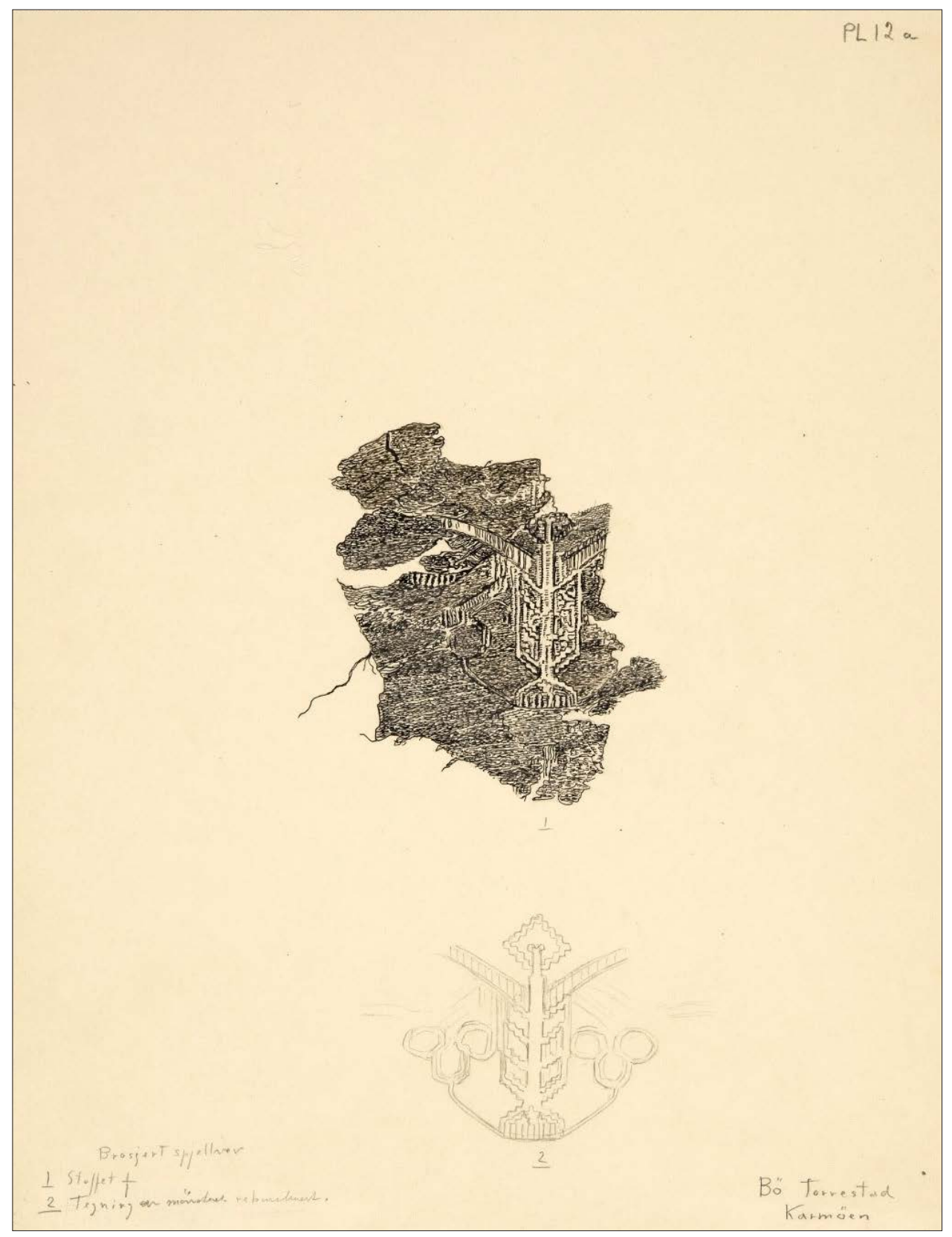

Planche 12a: Grønhaug, Bø, Torvestad, Rogaland. Brocheret spjceldvcev. Nr. 2: rekonstrueret mønster. Tegninger: Miranda Bødtker. 


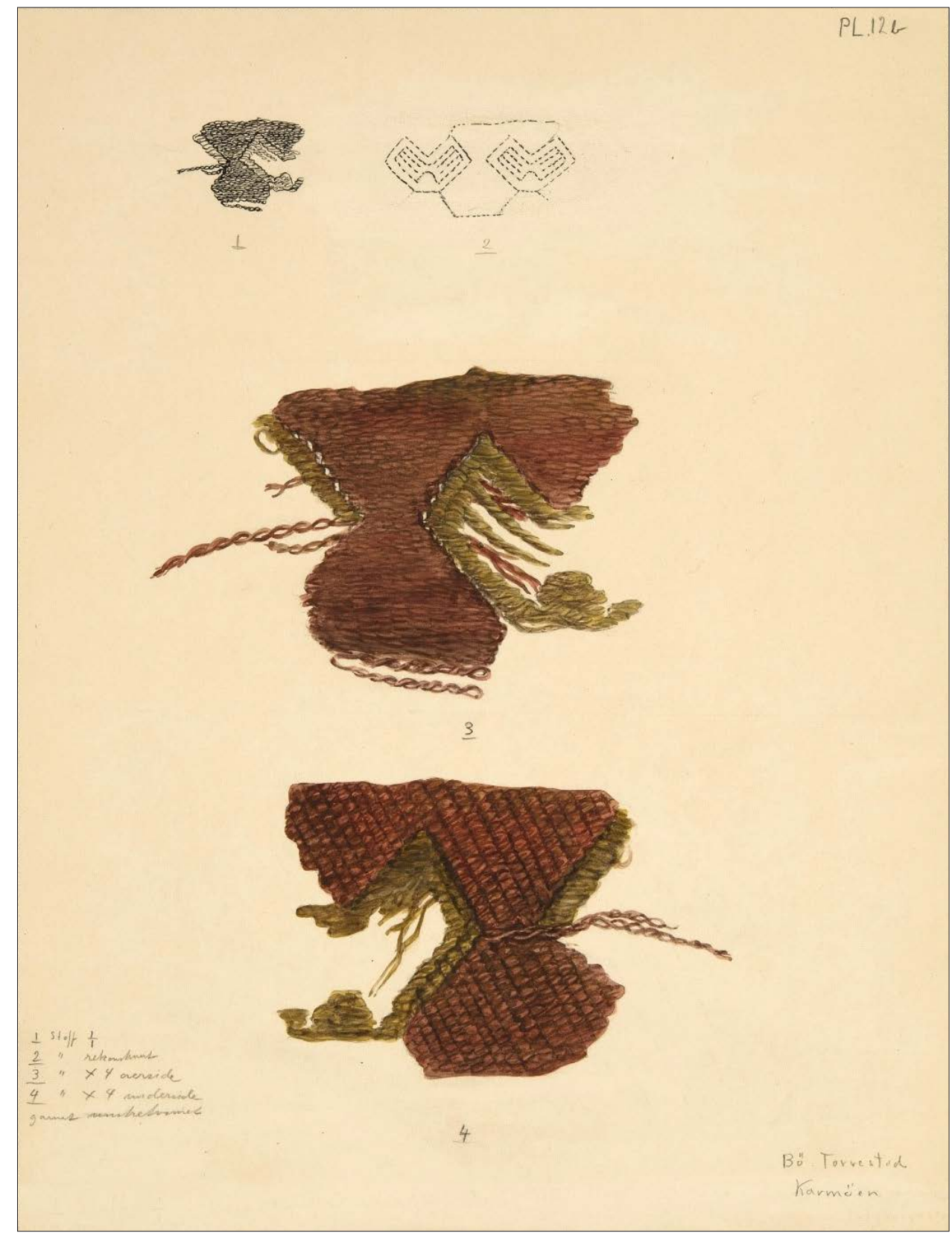

Planche 12b: Grønhaug, Bø, Torvestad, Rogaland. Brocheret spjoeldvcev, Nr. 1. Nr. 2: rekonstrueret mønster. Nr. 3: oversiden, firdobbelt størrelse, farvelagt. Nr. 4: undersiden, firdobbelt størrelse, farvelagt. Venstrespundet garn. Tegninger: Miranda Bødtker. 


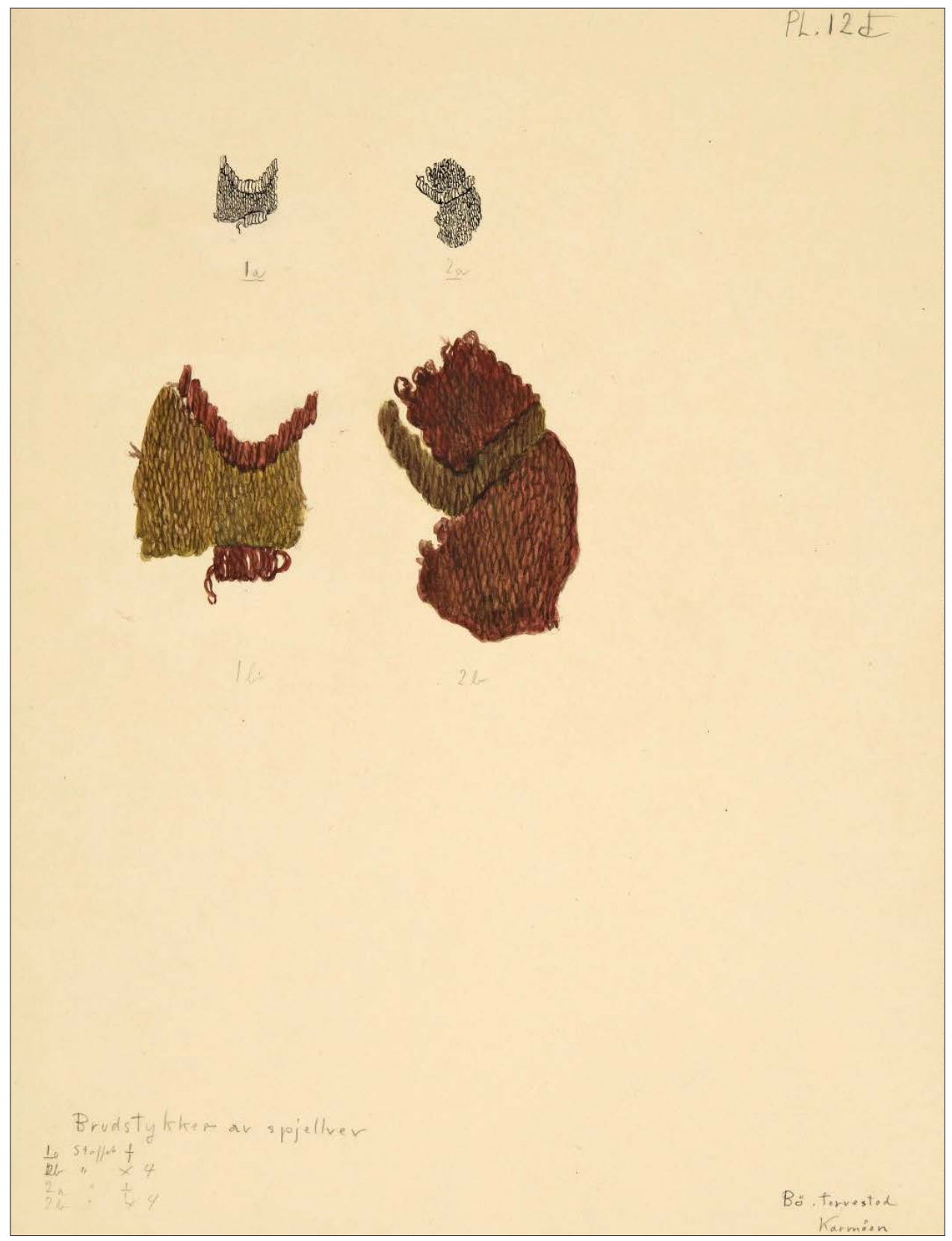

Planche 12c: Grønhaug, Bø, Torvestad, Rogaland. Brocheret spjceldvoev, Nr. 1a og 2a. Nr. $1 b$ og 2b: firdobbelt størrelse, farvelagt. Tegninger: Miranda Bødtker. 


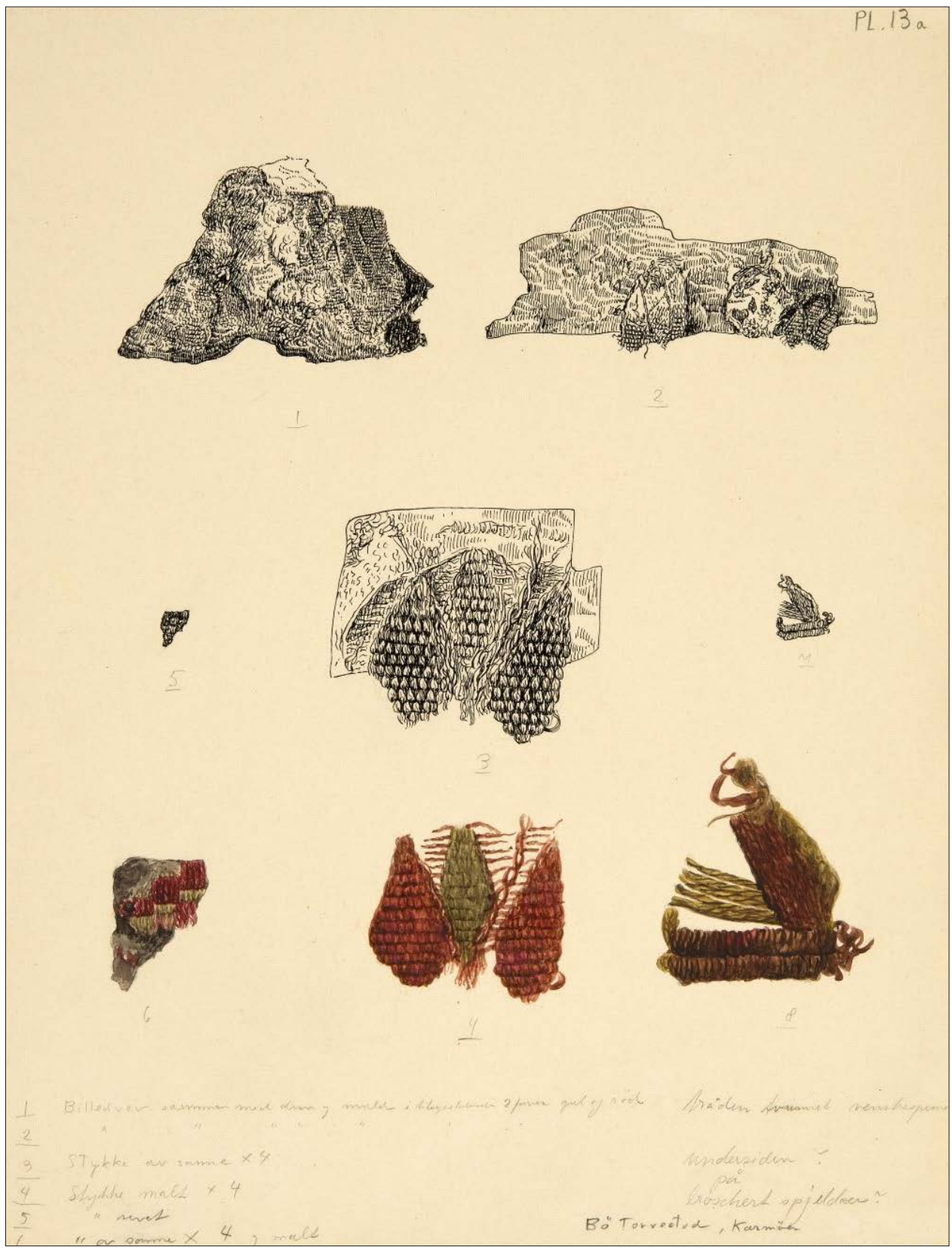

Planche 13a: Grønhaug, Bø, Torvestad, Rogaland. Billedvaevning med dun og smuld, i farverne gul og rød, $\mathrm{Nr} .1 \mathrm{og}$ 2. Undersiden af brocheret spjaldvaev. Nr. $5 \mathrm{og}$ 7: afrevne stykker. Tråden venstrespundet. Nr. 3, 4, 6 og 8: firdobbelt størrelse, Nr. 4, 6 og 8 farvelagt. Tegninger: Miranda Bødtker. 


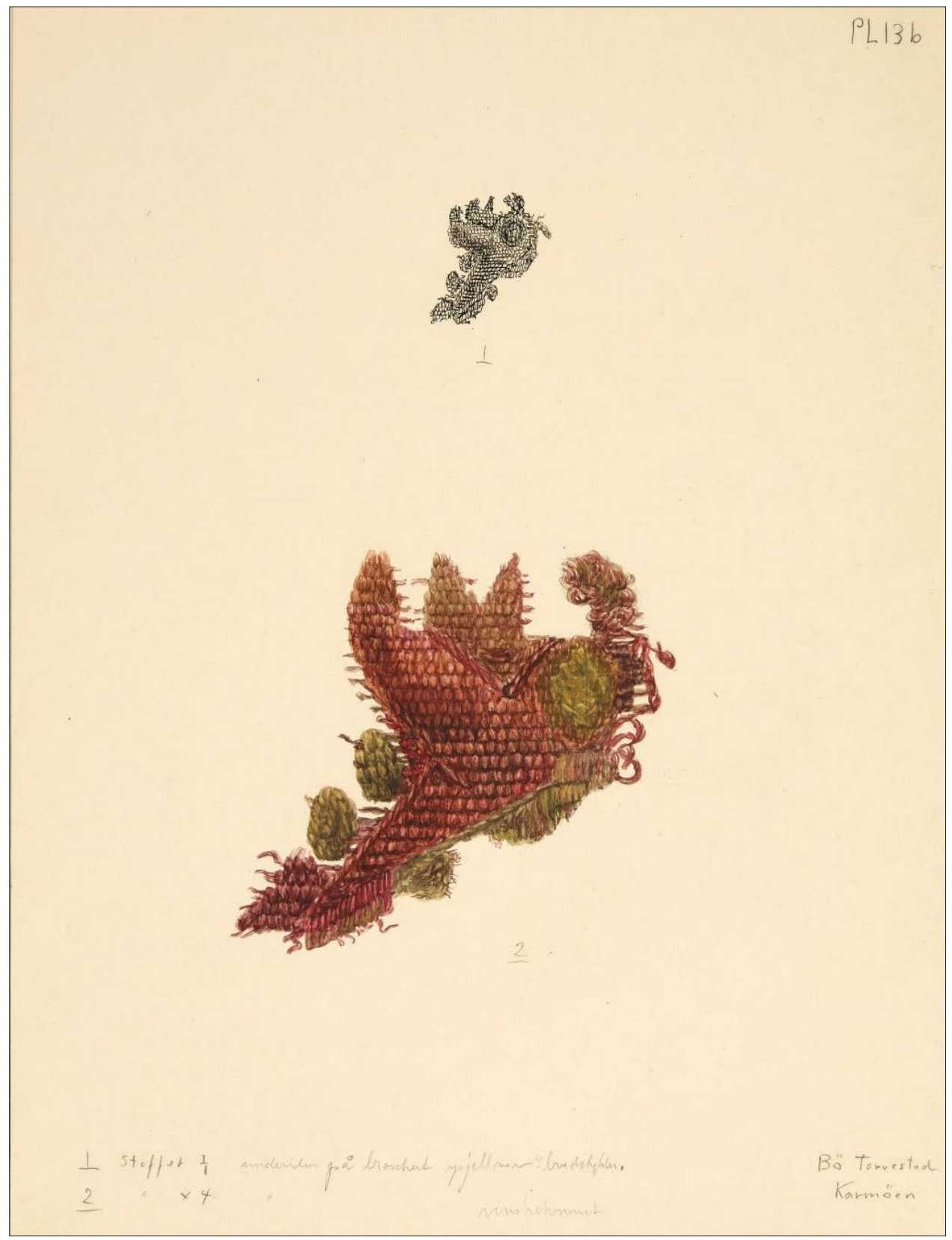

Planche 13b: Grønhaug, Bø, Torvestad, Rogaland. Undersiden af brocheret spjceldvcev, brudstykke, Nr. 1. Nr. 2: firdobbelt størrelse, farvelagt. Tegninger: Miranda Bødtker. 
af flere elementer, og tekstilerne fra planche 1 kan meget vel repræsentere bånd der indrammede egentlige billedvævninger.

Planche 14 viser to fragmenter af hvad Bødtker kalder gåseøiemønster men reelt er krystalkiper (for forskellen, se Bender Jørgensen 1986:13-14), i højrespundet (z) garn, med forstørrelser. Det drejer sig efter alt at dømme om krystalkiperstoffer af Birka-typen. Dette stof er ikke beskrevet hverken af Hiorth eller Bender Jørgensen. Birka-typen forekommer i en lang række skandinaviske gravfund fra merovinger- og vikingetid (Bender Jørgensen 1986:169-176). Den blev første gang beskrevet i materialet fra Birka (Geijer 1938), og tekstilerne er blevet anset som importerede luksusstoffer fra steder så forskellige som Frisland, Syrien, De britiske øer og Vest-Norge. Senest har isotop-analyser vist at de stammer fra Nordvesteuropa (von Holstein 2012).

Planche 15 viser baitrester med ull. Her er uden tvivl tale om kalfatring i form af uldklumper og tyk z-spundet uldtråd. Heller ikke dette er tidligere beskrevet fra Grønhaug-fundet. Derimod har uld og klude været almindelig brugt som kalfatring, og er påvist i en række arkæologiske fund, f. eks. bådfundet fra Øvre Tofte, Halsnøy (se nedenfor), og i Hedeby (Hägg 1984:15).

Planche 16 viser et kraftigt diagonalvevet uldkiperstof i højrespundet (z) garn, med betydelig tættere trend end islæt. Det har en kraftig søm, udført med s-tvundet tråd. Stoffet kan være det samme som planche 9. Der kan være tale om Bender Jørgensens type 4, der netop har sammensyning, og og Hiorths type c. Fotografier af tekstiler fra Grønhaug (Opedal 1998:72) viser fragmenter af billedvævningerne som Bødtker illustrerede i planche 11-13, dels fragmenter af uldkiper med påsyede snore, hvoraf et af sidstnævnte (betegnet 3) må være identisk med Bødtkers planche 16, og dermed sandsynligvis Bender Jørgensens type 4.

\section{Øvre Tofte, Halsnøy, Hordaland, B 5406.}

Resterne af en båd fra yngre romertid fra Øvre Tofte, Halsnøy, Kvinnherad i Hordaland blev fundet ved tørveskæring i en mose på Buneset, Toftevågen på Halsnøy i 1896, og blev samme år indleveret til Bergens Museum hvor den fik nummer B 5406 (Bendixen 1896:2830; Shetelig 1903:8-21). Det var bare dele af en båd der var nedlagt under to store sten, og der er sandsynligvis tale om et offerfund. Bådplankerne er C14-dateret til 335+/- 65 år (Myhre 1980; Sørnes 2012). Mellem bådens planker fandtes tøjstrimler, rester af bådens kalfatring.

Bødtker beskriver tekstilerne udførligt som rester af to forskellige stoffer i en følgeskrivelse til tegningerne. "Det første stoff som her skal omtales er på flere lange rimser ca $3 \mathrm{~cm}$ bredde og har muligens voert revet av et større stykke, brukt som plag. Mønsteret er bare synlig enkelte steder og er et gåseøiemønster. Renning og islett høirespunnet. På planche I $\mathrm{Nr}$. la og b vil man se stoffet festet til trestykket og $n r .2$ en rottrevle som nagle. Det andet stoff synes der å vare mindre av og det er pålagt dobbelt noget tynnere enn det første planche II Nr. 1, Mønsteret er rutekyper, renning høirespunnet, islett venstrespunnet. Begge stoffer har en rødbrun farve”. Tegningerne på planche 17 (Bødtkers planche I) Nr. 1a og 1b viser hvordan tøjstrimlerne fandtes på resterne af bådens træværk. Planche 17, nr. 3-5 viser tre forskellige forsøg på at beskrive det første stofs udseende og konstruktion. De to første viser stoffet i naturlig (?) og forstørret udgave, nr. 5 en skematisk gengivelse af bindingen. Endelig viser planche 17, nr. 6 prøver på garnet. Tilsvarende viser Planche 18 (Bødtkers planche II), nr. 1 det andet stofs placering på et større træstykke, formentlig i naturlig stør- 


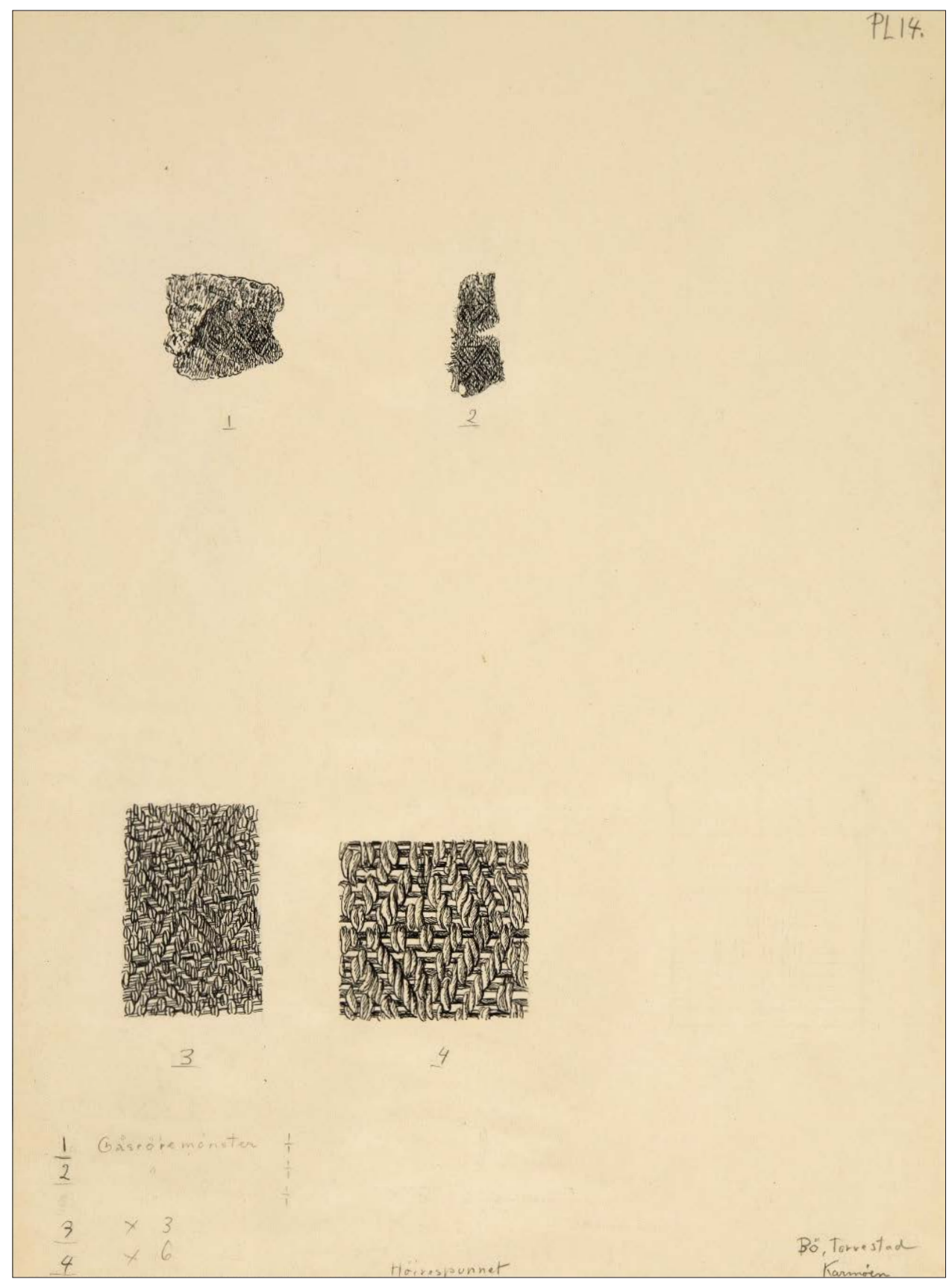

Planche 14: Grønhaug, Bø, Torvestad, Rogaland. Gåseøjemønster (krystalkiper), Nr. 1 og 2. Højrespundet. Nr. 3: tredobbelt størrelse. Nr. 4: seksdobbelt størrelse. Tegninger: Miranda Bødtker. 


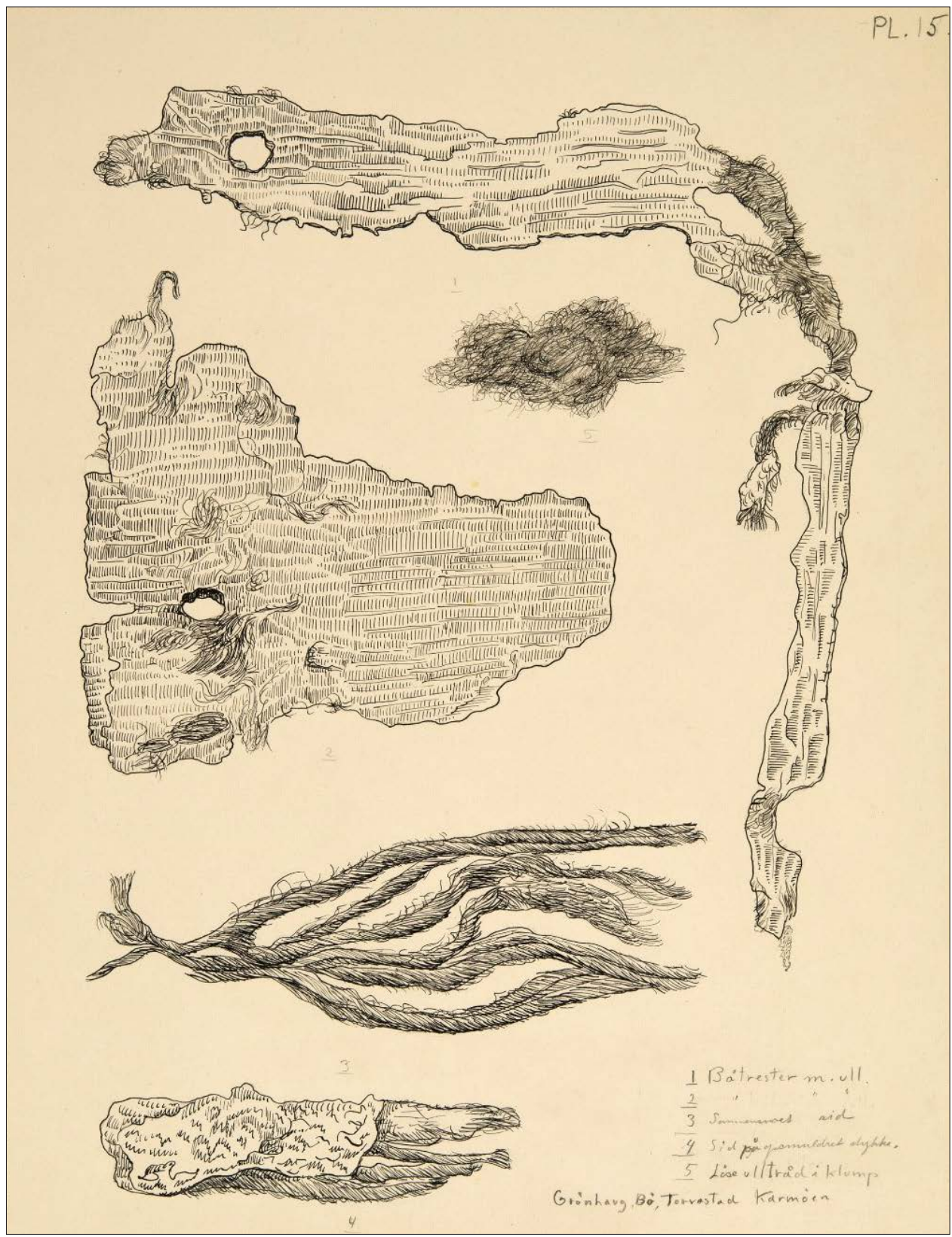

Planche 15: Grønhaug, Bø, Torvestad, Rogaland. Nr. 1 og 2: Bådrester med uld. Nr. 3: sammensnoede tråde. Nr. 4: siden af sammensmuldret stykke. Nr. 5: løse uldtråde i klump. Tegninger: Miranda Bødtker. 


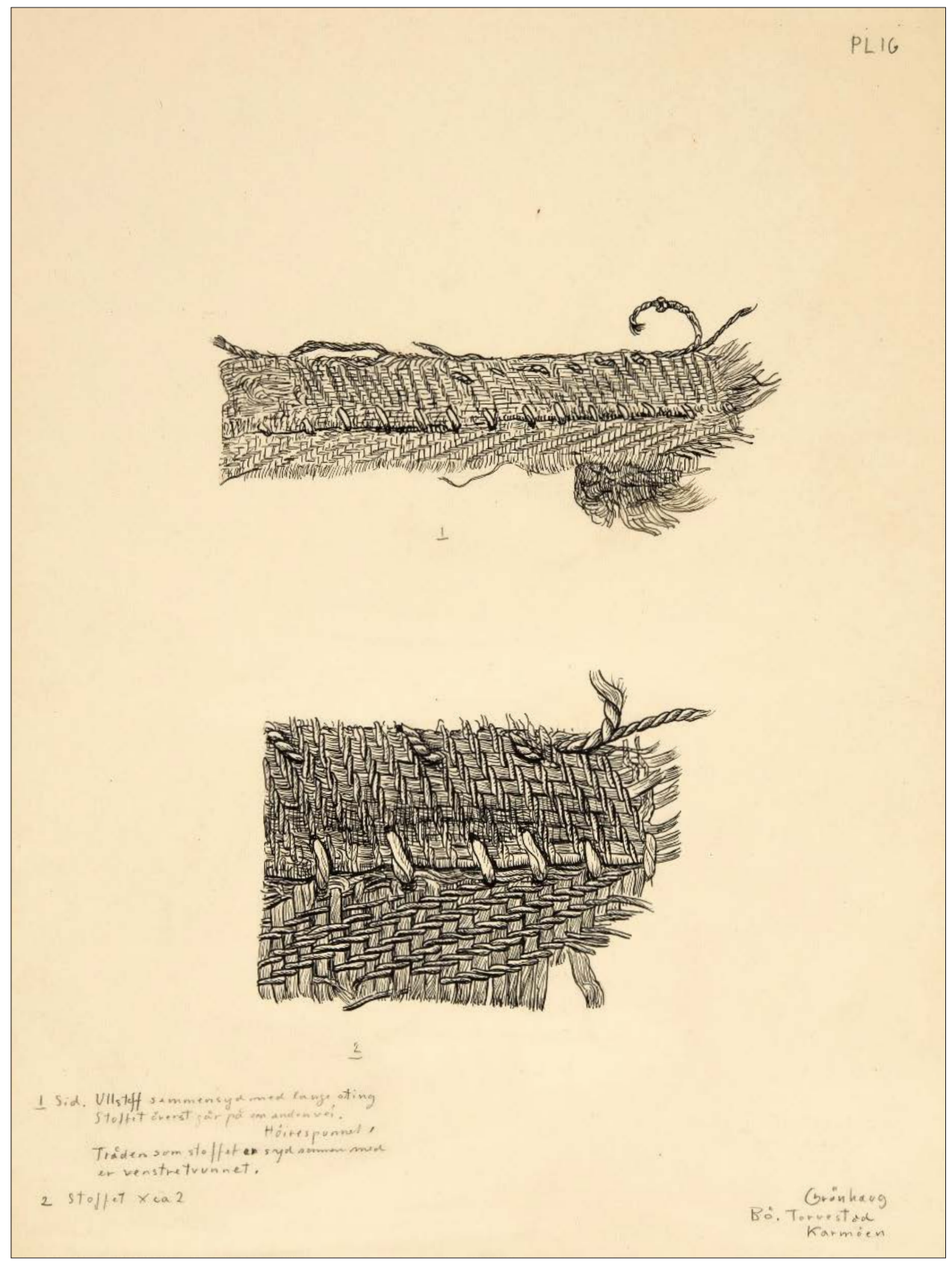

Planche 16: Grønhaug, Bø, Torvestad, Rogaland. Uldstof sømmet med lange sting, Nr. 1. Stoffet øverst vender den anden vej. Højrespundet. Sytråden er venstrespundet. Nr. 2: detalje, omtrent dobbelt størrelse. Tegninger: Miranda Bødtker. 


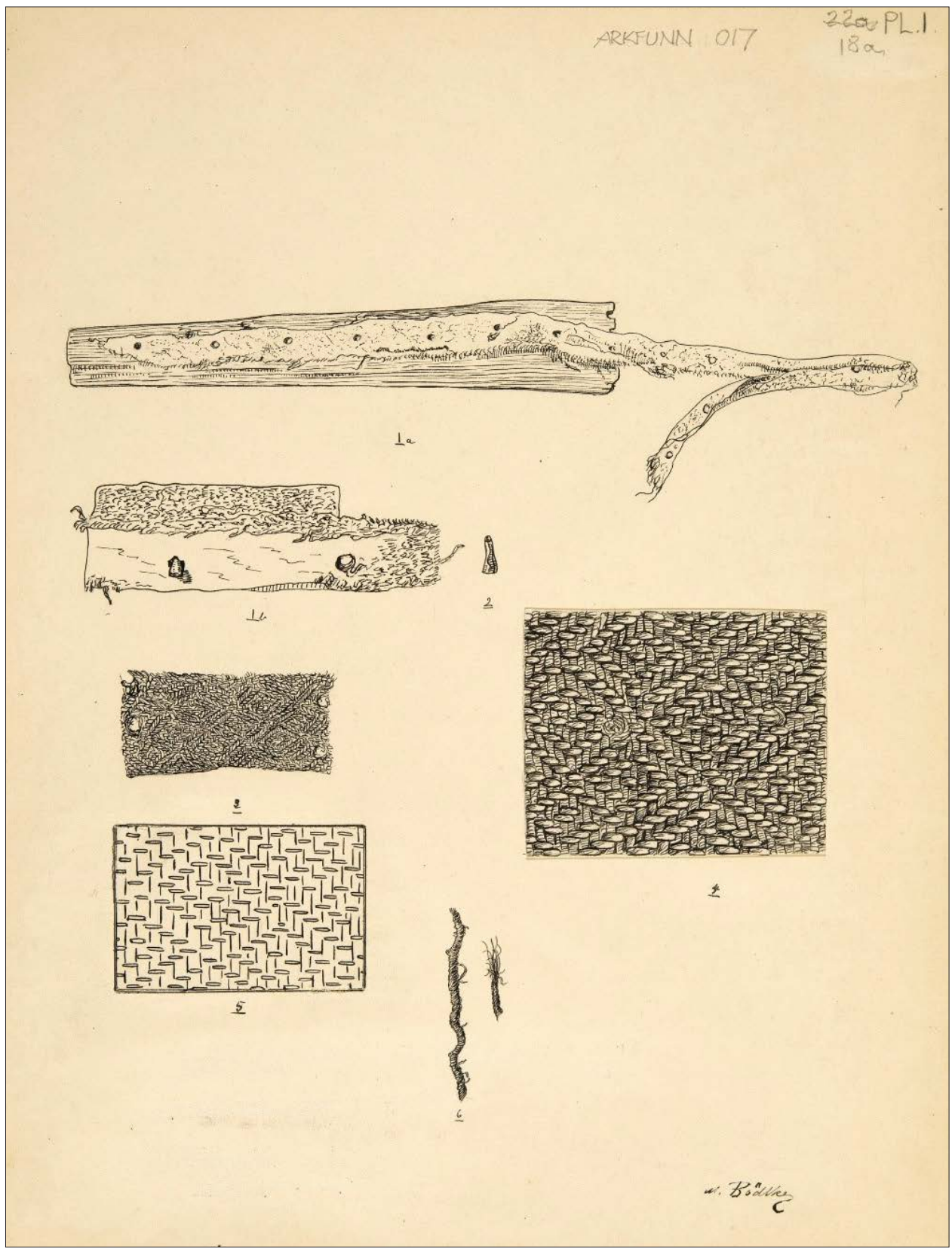

Planche 17: Øvre Tofte, Halsnøy, Hordaland. Tekstil på bådrester. Nr. 1a og 1b: stoffet fcestet til trcestykket. Nr. 2: Rodtrevle som nagle. Nr. 3: Stoffet. Nr. 4 og 5: Rekonstrueret. Nr. 6: Tråde. 


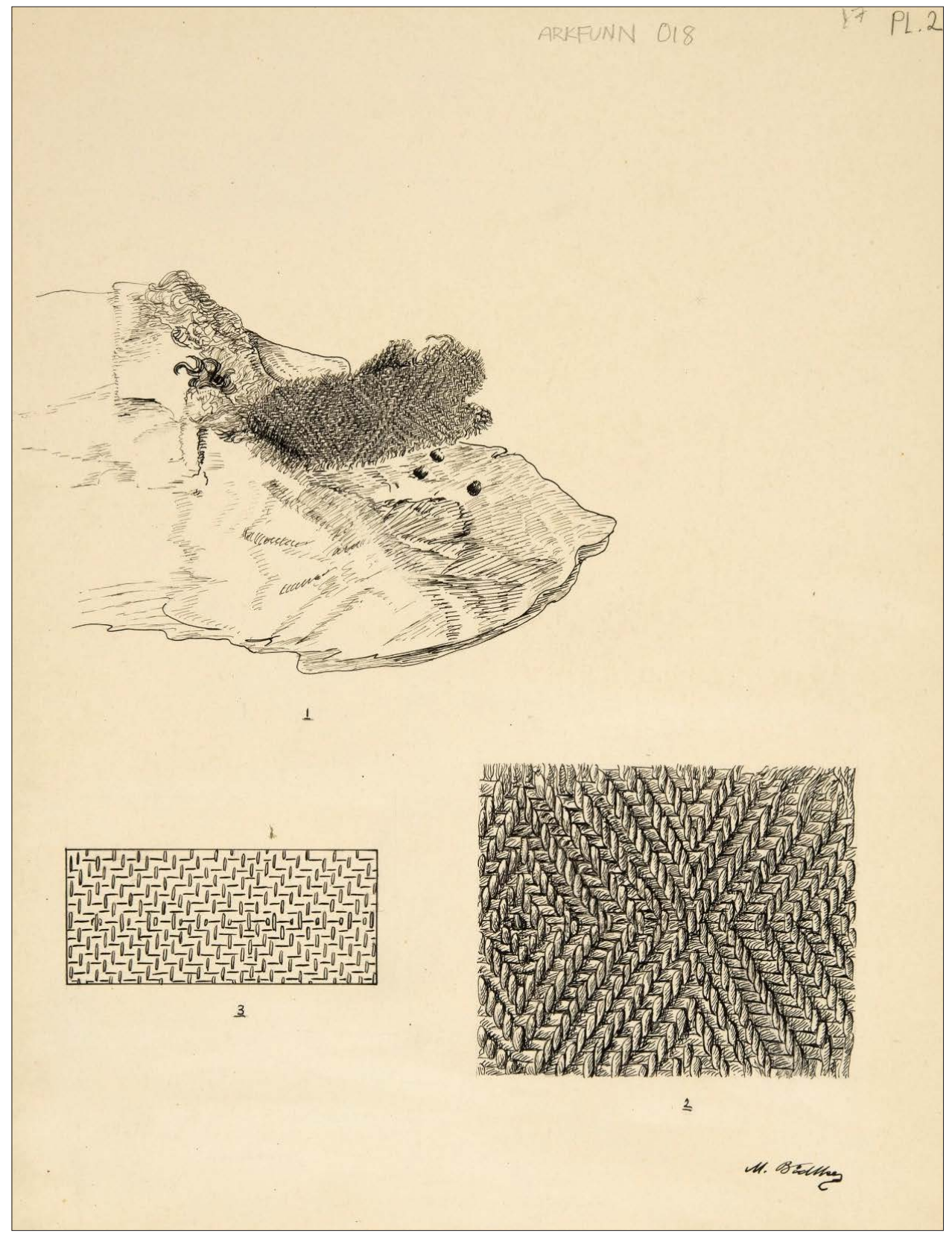

Planche 18: Øvre Tofte, Halsnøy, Hordaland. Tekstil på bådrester, Nr. 1. Nr. 2 og 3: rekonstrueret teknik. Mønsteret er rudekiper (krystalkiper), med højrespundet trend og venstrespundet islcet. Rødbrun farve. Tegninger: Miranda Bødtker. 
relse; planche 18, nr. 2 er en forstørret version, planche 18, nr. 3 en skematisk. I alle tilfælde opfatter Miranda Bødtker stofferne som gåseøje snarere end som krystalkiper.

Johan Hiorth (1908:15-16) beskrev tekstilerne fra Halsnøy som strimler af rødbrunt, toskaftet grovt uldtøj af hvid uld, tæt slået, med 15 tråde pr. cm². I slutningen af 1970-årene blev de undersøgt af Inger Raknes Pedersen og Bente Magnus, og i 1982 havde Lise Bender Jørgensen anledning til at se dele af dem. Nogle år senere foretog Penelope Walton fiber- og farveanalyser. Undersøgelserne konkluderede ligesom Bødtker at tøjstrimlerne stammer fra mindst to forskellige stykker stof, men ingen af dem er toskaftvævede, som foreslået af Hiorth. Det ene er vævet i $2 / 2$ krystalkiper med mønsterrapport 20/18, z/s-spundet garn, og 13-16/15-18 tråde pr. $\mathrm{cm}^{2}$, det andet er en 2/2 diagonalkiper, udført i pepitaternet spindemønster med skiftevis 4s og 4z-spundne tråde i både trend og islæt og 15/16 tråde pr. cm² (Magnus 1980; Bender Jørgensen 1986:245, kat. N:II:26); i sidstnævnte er museumsnumret fejlagtigt angivet som B1896. Tekstilerne er tydeligt rødfarvede. Farveanalyser af krystalkiperstoffet viste at det var farvet med krapp, Rubia tinctoria (Bender Jørgensen og Walton 1986:182). Detaljer ved tegningerne viser nogle af de elementer, som for tekstilarkæologen afslører den brudte kiper eller krystalkiper, men som Bødtker ikke har opfattet. Det er ikke let at se forskel på de to måder - gåseøje og krystalkiper - at danne et rudemønster på, især når objektet er næsten totusindårige fragmenter. Brug af forskelligt spundet garn i trend og islæt gør det yderligere vanskeligt, på grund af en drilagtig optisk virkning. Det har siden vist sig at gåseøje ikke forekommer i arkæologiske tekstiler fra Norden før vikingetiden (Bender Jørgensen 1986:172-173).

En anden diskrepans i forhold til tekstilarkæologernes resultater er at Bødtker opfatter både trend- og islætsgarnet i stoffet på planche 17 som z-spundet, i modsætning til de analyser som Inger Raknes Pedersen, Bente Magnus og Lise Bender Jørgensen er kommet frem til (Magnus 1980; Bender Jørgensen 1986:245). Den mest sandsynlige forklaring på dette er at Bødtker har opfattet det spindemønstrede diagonalkiperstof som gåseøje. Dette stof har både $\mathrm{z}-\mathrm{og} \mathrm{s}$-spinding i begge trådsystemer.

\section{Dale, Ytre Holmedal, (Sunnfjord), Sogn og Fjordane, B $3106 b$.}

Mandsgrav fra vikingetid med våben, redskaber og klinknagler, samt tre større tekstilfragmenter, hvoraf største stykke er 20 x $16 \mathrm{~cm}$. Fundet blev gjort ca. 1875 af grundejer Peder P. Dale i forbindelse med rydningen af en rund gravhøj, der oprindelig skal have været 4 alen høj, rejst over en uregelmæssig stenhob (Lorange 1877:51-52). Anders Lorange beskriver tekstilerne som "Tre rester av uldtøi, det ene stykke gult, de to andre brune med gule striber; på det største stykke, der er 7 tom langt og 4 tom bredt, ses en indvovet gul ring, omtrent $3 / 4$ tomme bred og 1 1/2 tomme $i$ indvendig diameter, hvis traade på vrangen danner lange løse ender (3106b)" (Lorange 1877: 52).

Dette svarer godt til Miranda Bødtkers tegning og beskrivelse. Hun angiver "tykt brunt stoff med gulbrun ring, diagonalvev". Tegningen på planche19 viser et fragment på 20 x 12 $\mathrm{cm}$ med en D-formet figur udført i lysere garn. En detaljtegning viser et udsnit af dette. Bødtker angiver ingen oplysninger om spinderetning, eller hvad hun anser for trend og islæt. At dømme udfra tegningen er de vandrette tråde trend, de lodrette islæt; det D-formede mønster er udført i islætten. Bødtkers tegning antyder at der er tale om en interlink-teknik.

I 1982 havde Lise Bender Jørgensen anledning til at se tekstilerne fra Dale, og bestemte dem som i 2/2 kiper med indvævet mønster (billedvævning), z/z spinding, og 8/6 tråde pr. 


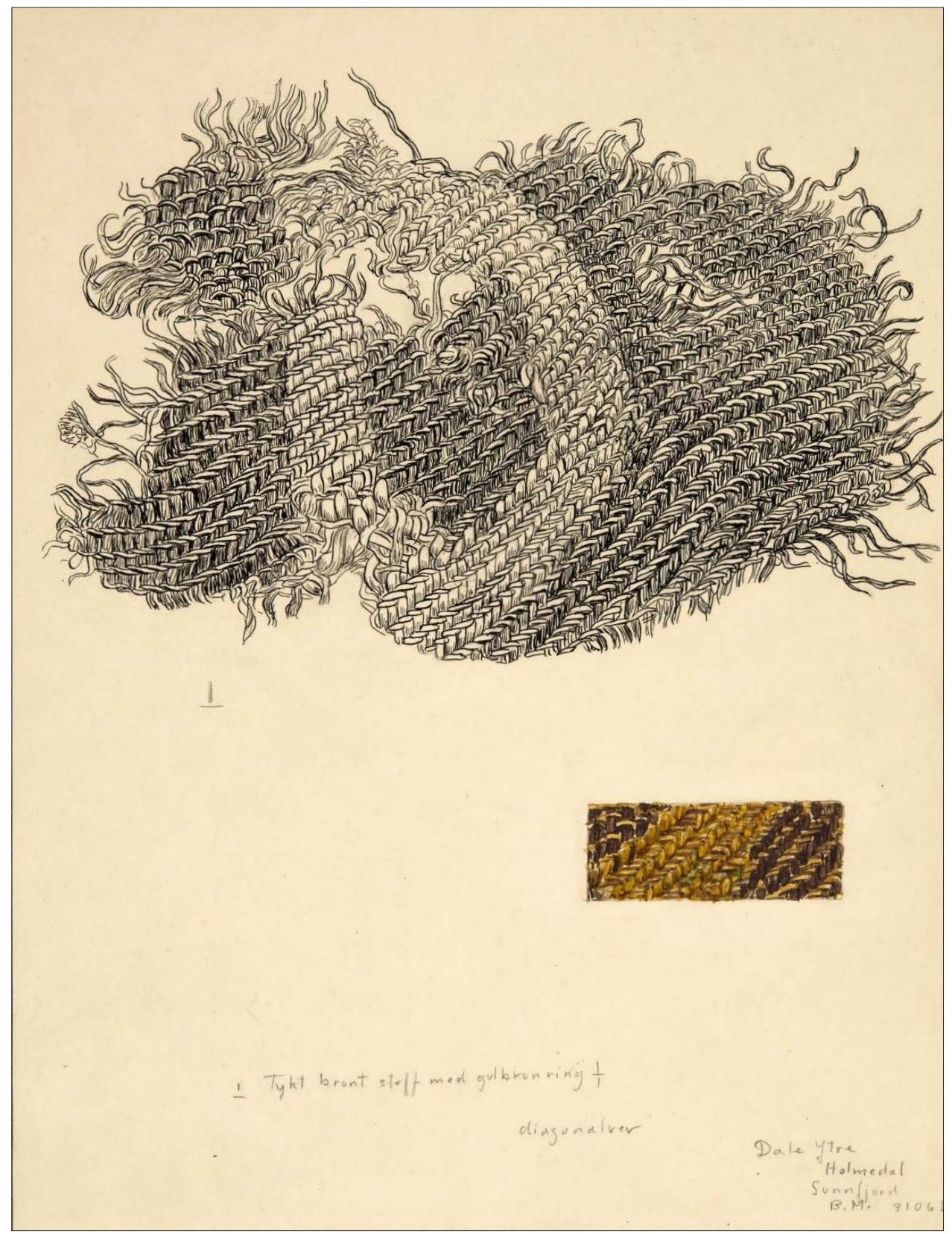

Planche 19: Dale, Ytre Holmedal, Sunnfjord, Sogn og Fjordane. Tykt brunt stof med ring. Diagonalvaevet. Indsat farvelagt detalje. Tegninger: Miranda Bødtker. 
cm² $^{2} 3$ farver tråde (Bender Jørgensen 1986:265, kat. N:V:74); ellers har dette fund ikke været genstand for forskernes interesse.

Døsen, Sogn \& Fjordane, B 6091.

Gravfund fra folkevandringstid fra Haug IV, Døsen, Os i Hordaland, udgravet af Haakon Shetelig i 1906 (Shetelig og Brøgger 1908). Lokaliteten rummede flere gravhøje der blev undersøgt af Shetelig og udførligt beskrevet i hans Vestlandske graver fra jernalderen (Shetelig 1912:121-149). To grave i henholdsvis høj II og høj IV rummede tekstilrester, deriblandt uldtæpper, dragtrester, brikvævning med mere. Begge grave dateres til det 6 . århundrede e. Kr. Tekstilerne fra høj IV, grav 2 er beskrevet af Johan Hiorth (1908:17) og Bjørn Hougen (1935:79-80); tekstiler fra begge grave er beskevet af Lise Bender Jørgensen (1986:254, kat. N:III:71-72) og af Margareta Nockert (1991:46-47). Graven fra høj IV er en mandsgrav. Afdøde var, tilsynelandende fuldt påklædt, svøbt i to store uldtæpper. Det ene er ca. $150 \mathrm{~cm}$ bredt og lagt på skrå. Ovenpå lå det andet, der var større og tyndere; over dette var et meget fint og tyndt stykke stof bredt ud. Det hele var lagt på et bjørneskind (Shetelig 1912:139-148).

Hiorth (1908:17) beskriver de to uldtæpper, a) som et brunt firskaftet uldtøj med trend af grov, sort uld og islæt i tyndere, løst spundet hvid uld, 6 og 4 tråde pr. $\mathrm{cm}^{2}$ med spor af luv på begge sider; b) som et ensfarvet brunt, firskaftet stof, tykkere og mere tætvævet, med 10 og 12 tråde pr. $\mathrm{cm}^{2}$. Hougen (1935:80) beskriver tilsvarende tæpperne som oprindelig tykke og lodne, vævet i 2/2 kiper. Det ene har ca. 6/6 tråde pr. $\mathrm{cm}^{2}$, det andet er tættere vævet end det andet. Et har en smal brikvævet bort langs den ene side. Dragtresterne er dårligere bevaret, med undtagelse af to afrevne ærmer, 40-45 cm lange. De er ca. $30 \mathrm{~cm}$ vide foroven, og syet med 1, hhv. 3 kiler. Igen ses smalle brikvævede kanter i sømmene. De måler bare ca. $7 \mathrm{~cm}$ ved håndleddet, hvor stoffet er bøjet om til en ca. $7 \mathrm{~cm}$ bred søm. Stoffet er 2/2 kiper med 12-14 tråde pr. cm² i begge trådsystemer. Dertil kommer yderligere et antal kiper-fragmenter samt rester af mønstret brikvævning (Hougen 1935:80). Nockerts og Bender Jørgensens beskrivelser følger i store træk Hougens, og lægger til at garnet er z-spundet (Bender Jørgensen 1986:254; Nockert 1991:46-47).

Miranda Bødtkers materiale omfatter tre tegninger af kipervævninger, beskrevet som Diagonalvevet stoff, grissent, tynt, $n$ st. Høirespunnet (planche 20, nr. 1 og nr. 2); Diagonalvevet stoff, grissent, tykt, meget grissent (nr. 3). Yderligere tre tegninger, nr. 4, nr. 5 og nr. 6: $1 \mathrm{~cm}$ stoff $x$ 4. Farven brun. Endelig en tegning (x2) af tråd, med betegnelsen tråden ujevnt tyk.

De tre forstørrede tegninger af stofprøver viser 3 forskellige grader af tæthed. 4 er en velbalanceret $2 / 2$ kiper, hvor garnets tykkelse udfylder mellemrummene. 5 viser en mere åben væv, med tydelige mellemrum mellem trådene, mens 6 har mellemrum der er ligeså brede som garnerne. Tegningerne må opfattes som prøver, eksempler på det righoldige tekstilmateriale fra Døsen høj IV, grav 2, og svarer godt til Hougens, Bender Jørgensens og Nockerts bestemmelser.

Blimshaugen, Blindheim, Vigra, Møre og Romsdal, B 8628.

Blimshaugen er en gravhøj fra 4. årh. e. Kr. Den indeholdt fem grave, en brandgrav og fire ubrændte grave (Magnus 1988). Fundene fra højen er registreret med museumsnumrene B 5669, B 8628, B 9283. Brandgraven B 5669 blev fundet i 1901. Den er fra folkevandrings- 


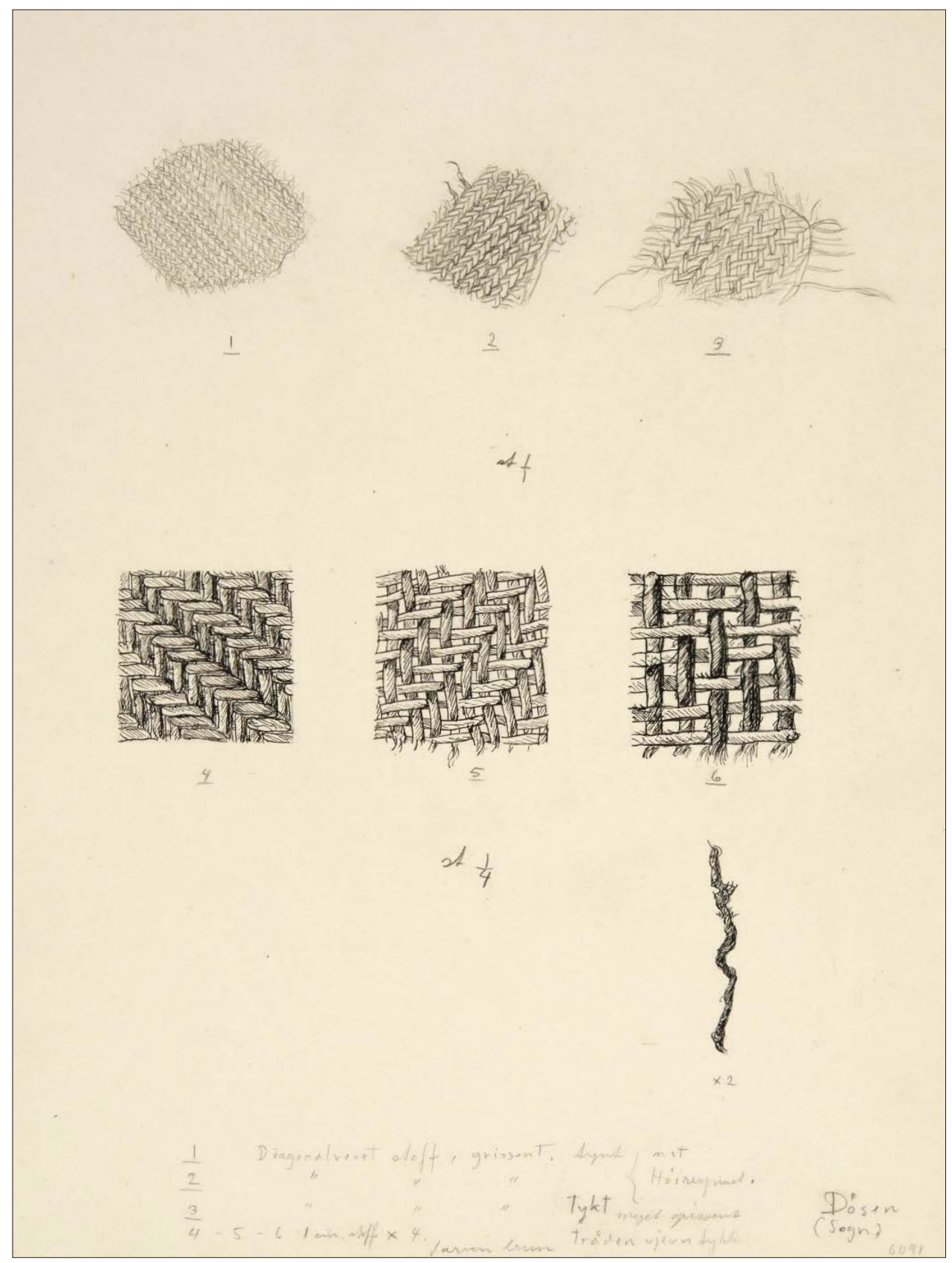

Planche 20: Døsen, Sogn og Fjordane. Nr 1 og 2: diagonalvavet stof, mest højrespundet. Nr. 3: tykt diagonalvavet stof. Farven brun, tråden ujcevn. Nr. 4-6: firdobbelt størrelse. Tegninger: Miranda Bødtker. 
tiden, og indeholdt ingen tekstilrester. B 8628 omfatter en kvindegrav, en barnegrav og en mandsgrav. De blev udgravet i 1934 af Eva Nissen Meyer og kortfattet beskrevet i Bergens Museums tilvekst for 1934 (Bøe \& Nissen Meyer 1935:47-54). Den sidste grav, B 9283, blev udgravet i 1942 af Eva Fett (f. Nissen Meyer) og Per Fett (Fett 1943:24). Der blev fundet tekstilrester i alle de tre grave fra udgravningen i 1934 (B 8628), men ikke i B 5669 og B 9283. Tekstilerne fra 1934-udgravningen er beskrevet i Bjørn Hougens afhandling Snartemofunnene (Hougen 1935). Mandsgraven indeholdt bare småstykker, vistnok i firskaft (2/2 kiper). I barnegraven var der ganske store mængder af tøj, men så stærkt opløst at videre bestemmelse er umulig, omend det meste ser ud til at være firskaft, og et ganske lille stykke en reps-agtig toskaft. Kvindegravens tekstiler er af større interesse, omend de også er i dårlig forfatning. De er alle af samme type 2/2 kiper, med trådtal på omkring 18/12 tråde pr. $\mathrm{cm}^{2}$ Et af dem er ternet $\mathrm{i}$ to forskellige farver, og kantet med en 3,7 cm bred brikvævet bort. Dette dokumenteres af to tekniske tegninger, rentegnet af Mary Wilhelmsen efter Hougens anvisning, samt et fotografi (Hougen 1935:64-65, og planche XII 2). Tekstilerne blev ikke konserveret inden de indgik i det lokale museums udstilling; det skete først i 1976 da de blev hentet til Historisk Museum i Bergen, hvor Bente Magnus og Inger Raknes Pedersen undersøgte dem og senere nypublicerede dem (Magnus 1988, Raknes Pedersen 1988). Raknes Pedersen påviste tre forskellige typer tekstiler i kvindegraven. Type 1 , en $2 / 2$ kiper med påsat brikvævet bort, er det samme som Hougen beskrev; Raknes Pedersen lægger nogle flere detaljer til. Type 2 er en krystalkiper, type 3 er en 2/2 kiper med spindemønster, og et af fragmenterne er afsluttet med en brikvævet bort. Fra mandsgraven forelå en klump tekstiler der ikke beskrives nærmere. Barnegraven indeholdt to klumper samt to små fragmenter i fin lærredsvævning. I 1982 havde Lise Bender Jørgensen også anledning til at studere tekstilerne, der omfattede et stort fragment i ternet kiper og brikvævet bort, svarende til Hougens og Raknes Pedersens beskrivelser; et lille stykke i fin reps, samt en klump af 2/2 kiper med omkring 10/10 tråde pr. cm² (Bender Jørgensen 1986:245, kat. N:II:27-28).

Miranda Bødtkers dokumentation af Blindheim-tekstilerne omfatter 3 tegninger af udsnit af kipervevninger, fordelt på 2 plancher der her er samlet til én. De er hhv. betegnet som "stoff i firskaftet diagonalkyper på forskellig vei og meget grissen", "grovt grissent diagonalvev" og "fint grissent diagonalvev". Desuden angives det at "Begge stofferne ligger sammenpresset". Der er ingen nøjere beskrivelse af stofferne. Stoffet på planche $21 \mathrm{er}$ efter alt at dømme en brudt kiper eller krystalkiper, hvor i al fald én brudlinie kan ses på tegningen. Tegningen viser tillige tekstilfragmentets form.

Bødtkers oplysninger kunne stemme med barnegraven, hvor den døde var dækket af 6-8 tykke kager af stof; under dette fandtes fragmenter af et meget finere stof. Dette sidstnævnte er imidlertid senere bestemt som lærreds- eller repsvævet (Bender Jørgensen 1986:245), hvilket ikke passer med Bødtkers oplysninger. Der er snarere tale om tekstilerne fra kvindegraven, hvor Raknes Pedersen har påvist tre forskellige kipervævninger, hvoraf det ene er prydet med brikvævet bånd. Dette er vævet i 2/2 kiper med 14/12 tråde pr. cm²; garnet er hovedsagelig z-spundet, men i det ene system optræder såvel z- som s-spundet garn, hvilket viser at stoffet var spindemønstret. Stoftype 2 er bestemt som en krystalkiper, vævet med Z-spundet garn i et system, s-spundet garn i det andet, og med 21/16 tråde pr. $\mathrm{cm}^{2}$. Der er bevaret et stort stykke samt et antal småfragmenter. Stoftype 3 er vævet i $2 / 2$ kiper, med 20/18 tråde pr. $\mathrm{cm}^{2}$; det er spindemønstret i såkaldt pepitatern. Tekstilerne fra mandsgraven beskrives blot som en klump af tekstiler (Raknes Pedersen 1988). Bødtkers tegning øverst 


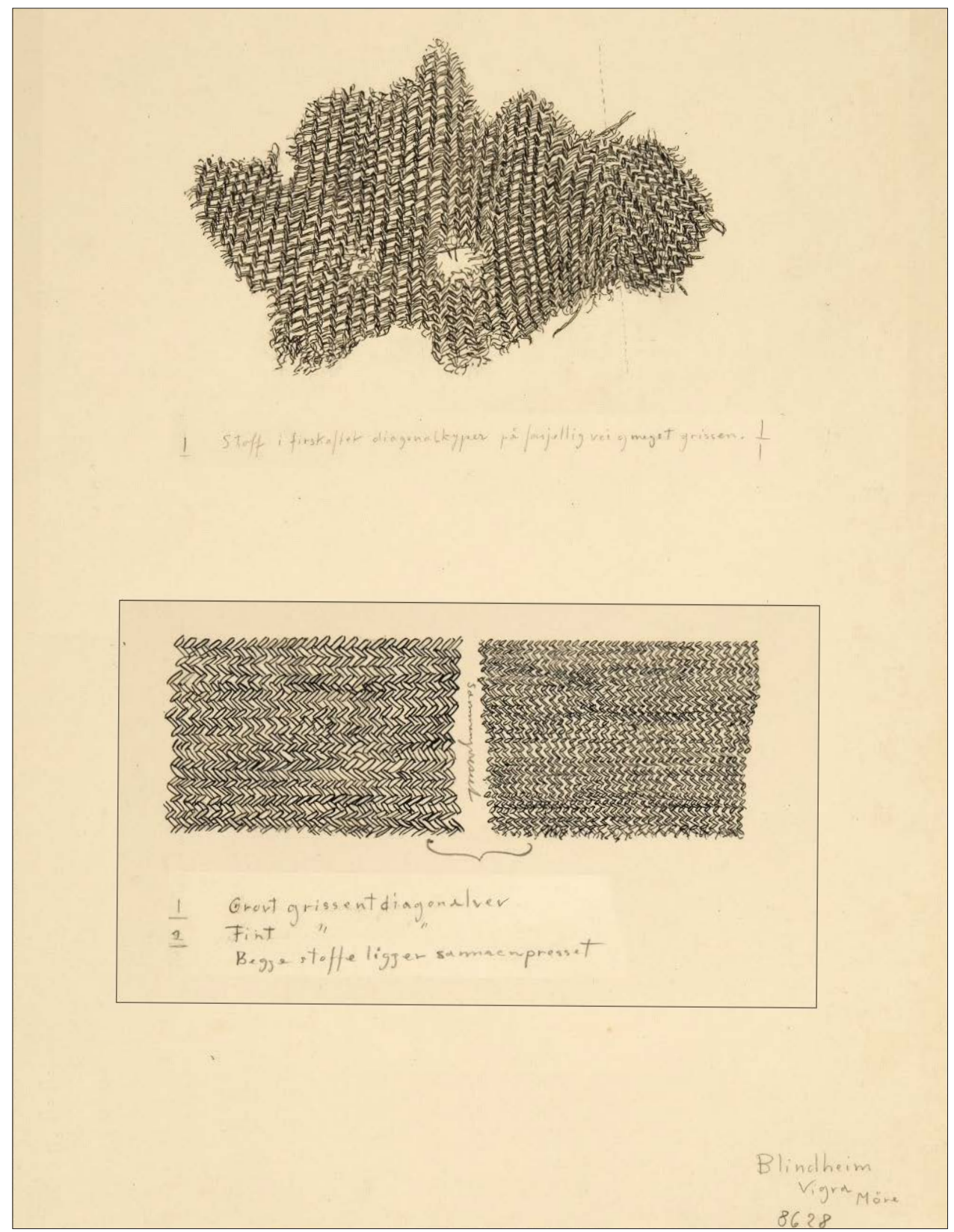

Planche 21: Blimshaugen, Blindheim, Vigra, Møre og Romsdal. Øverst: stof i fireskaftet diagonalkiper på forskellig vej. Nederst (indsat): 1: groft diagonalvavet stof. 2: Fint diagonalvavet stof. Begge stoffer ligger sammenpresset. Tegninger: Miranda Bødtker. 
på planche 21 viser sandsynligvis et fragment af Raknes Pedersens type 2, mens tegningerne nederst kan vise prøver på Raknes Pedersens type 1 og 3 .

\section{Tegningerne som arkæologisk kildemateriale}

Hvad fortæller Miranda Bødtkers tegninger os? De viser en detaljerigdom der er næsten chokerende, selv for en der har set de originale tekstiler og forsøgt at beskrive dem. Bødtkers tegninger af tekstilerne fra Grønhaug viser adskillige elementer der ikke er fanget op af andre forskere, og åbner muligheder for nye indsigter i tidens formsprog og væveteknik. De farvelagte plancher gør det klart at her er et uudnyttet potentiale for farveanalyser. Dele af billedvævningerne fra Grønhaug viser klare ligheder med Oseberg-fundets, og antyder at der er tale om et veletableret formsprog. Dertil kommer tekstiler der kan knyttes til det maritime, såsom rester af sejl eller telt samt kalfatringen. Billedvævningen fra Dale er udført i en teknik der ikke umiddelbart kan kendes igen, og fortjener nærmere undersøgelse der også omfatter farveanalyser. Bødtkers tegninger af jernaldertekstiler er bedre dækket ind af forskningen, men giver værdifulde indblik i hvordan tidens tand påvirker museernes samlinger. At Bødtkers tegninger omfatter flere eksempler på tekstiler der ikke er blevet registreret af tekstilforskerne som har studeret andre dele af de samme fund er iøjnefaldende og kalder på nærmere undersøgelser. Hvor var de da Hiorth, Hougen og Bender Jørgensen gennemgik materialet? Er de bortkommet, er det sket en forveksling eller sammenblanding med andre fund, eller har de måske bare været til konservering eller udlånt?

Miranda Bødtkers tegninger fokuserer i høj grad på tekniske detaljer, mens det er motiverne der er i centrum for Sofie Kraffts og Mary Storms gengivelser af Oseberg-tekstilerne. Det betyder at de rummer forskellige oplysninger og muligheder for at fortælle andre historier. Det skyldes delvis at Bødtkers materiale er langt mere fragmenteret, og at billedvævningerne stort set mangler genkendelige motiver. Krafft og Storm havde bedre bevaret materiale at arbejde med, og selvom deres tegninger også viser tekniske detaljer, er det ikke her de har lagt hovedvægten af deres indsats. Bødtkers blik for små detaljer og interesse for vævning spiller givetvis også ind. De kvaliteter der gjorde at hun kunne illustrere centrale botaniske værker som Norsk flora, fremgår ligeså tydeligt af hendes tegninger af de arkæologiske tekstiler. Der er enkelte diskrepanser mellem Bødtkers og tekstilforskernes analyser. De viser at tolkningen afhænger af øjnene der ser, og at det kan være nyttigt at undersøge materialet igen, med friske øjne, opdateret kundskab og nye metoder.

Vi kan konkludere med at tegningerne står distancen som videnskabelig dokumentationsform og fortsat kan bidrage til forskningen. Miranda Bødtkers tegninger, især af tekstilerne fra Grønhaug og Dale, må betegnes som en arkæologisk skatkiste der fortjener at blive udforsket til bunds.

\section{Tak}

En varm tak til tekstilkonservator Hana Lukešová, Universitetsmuseet i Bergen, der har hjulpet med en række oplysninger, til Aud Beverfjord, der har sat fire af Miranda Bødtkers tegninger sammen til to, og til to anonyme fagfæller der har givet værdifulde tips til forbedring af manuskriptet. 


\section{Litteratur}

Bender Jørgensen, Lise

1986 Forhistoriske textiler i Skandinavien / Prehistoric Scandinavian Textiles. Det Kongelige Nordiske Oldskriftselskab, København.

Bender Jørgensen, Lise og Penelope Walton

1986 Dyes and fleece types in prehistoric textiles from Scandinavia and Germany. Journal of Danish Archaeology 5:177-188.

Bendixen, Bendix E.

1896 Fornlevninger i Sønderhordland. Foreningen til norske fortidsminders bevaring, Aarsberetning for 1896:18-45.

Bonde, Niels \& Frans-Arne Stylegar

2009 Fra Avaldsnes til Oseberg. Dendrokronologiske undersøkelser av skipsgravene fra Storhaug og Grønhaug på Karmøy. Viking LXXII:149-168.

Broholm, Hans Christian og Margrethe Hald

1940 Costumes of the Bronze Age in Denmark. Nyt Nordisk Forlag/Arnold Busck, Copenhagen.

Bødtker, Miranda

1970 Norsk flora (illu. bd.1), redigert av Rolf Nordhagen. Aschehoug \& Co, Oslo.

Bøe, Johannes, og Eva Nissen Meyer

1935 Bergens Museums tilvekst av oldsaker 1934. Bergens Museums Aarbok 1934: kapitel 2.

Christensen, Arne Emil og Margareta Nockert (red)

2006 Osebergfunnet Bind IV. Tekstilene. Kulturhistorisk Museum, Universitetet i Oslo, Oslo.

Fett, Per

1943 Bergens Museums tilvekst av oldsaker 1943. Bergens Museums Aarbok 1943: kapitel 4.

Geijer, Agnes

1938 Birka III. Die Textilfunde aus den Gräbern. Almqvist \& Wiksells Boktryckeri, Uppsala.

Hald, Margrethe

1950 Olddanske tekstiler. Komparative Tekstil- og Dragthistoriske Studier paa Grundlag af Mosefund og Gravfund fra Jernalderen. Det Kongelige Nordiske Oldskriftselskab, København.

1980 Ancient Danish Textiles from Bogs and Burials. A Comparative Study of Costume and Iron Age Textiles. The National Museum of Denmark, Copenhagen.

Hägg, Inga

1984 Die Textilfunde aus dem Hafen von Haithabu. Berichte über die Ausgrabungen in Haithabu Bericht 20. Karl Wachholtz Verlag, Neumünster.

Hiorth, Johan

1908 Undersøgelser af forhistorisk uld og tøirester fundne i norske gravhauger.

Stavanger Museums Arshefte 1908, artikel III:1-24.

Hougen, Bjørn

1935 Snartemofunnene: Studier i folkevandringstidens ornamentikk og tekstilhistorie (Norske oldfunn

7), Universitetets oldsaksamling, Oslo.

Kjellmo, Ellen

1996 Båtrya i gammel og ny tid. Orkana Forlag, Svolvær.

Korsmo, Eli Kristine

2006 Lar flere bli kjent med Miranda, $P A$ HØYDEN, https://pahoyden.no/lar-flere-bli-kjent-medmiranda/309519 (besøgt 14.02.20).

Lorange, Anders

1877 Fortegnelse over oldsager indkomne i 1876 til Bergens Museum. Foreningen til norske

fortidsminders bevaring, Aarsberetning for 1876:49-60. Kristiania.

Magnus, Bente

1980 Halsnøybåtens tekstiler. Arkeo 1980:22-25. 
1982 A Chieftain's Costume. I Textilsymposium Neumünster, Archäologische Textilfunde 6.5-8.5.1981, redigeret af Lise Bender Jørgensen og Klaus Tidow, s. 63-74. Textilmuseum Neumünster, Neumünster.

1983 How was he dressed? New light on the garments from the grave at Evebø / Eide in Gloppen, Norway. Studien zur Sachsenforschung 4:293-303.

1988 Blimshaugen - a Fourth Century Mausoleum. I Archaeological Textiles, Report from the 2nd NESAT Symposium 1.-4.V. 1984, redigeret af Lise Bender Jørgensen, Bente Magnus og Elisabeth Munksgaard, s. 109-115. Københavns Universitet, København.

Moe, Dagfinn (red.)

2006 Miranda Bødtker 1896 -1996, 100 år $i$ kunsthåndverkets og dokumentasjonens tjeneste. Bergen Museums Skrifter nr. 20. Symbolon AS, Bergen.

Myhre, Bjørn

1980 Ny datering av våre eldste båter. Arkeo 27:27-30.

Nockert, Margareta

1991 The Högom find and other Migration period textiles and costumes in Scandinavia. The Högom find and other Migration period textiles and costumes in Scandinavia. University of Umeå,

Nordhagen, Rolf Department of Archaeology, Umeå.

1940 Norskflora. (tekst bd.). Aschehoug \& Co, Oslo.

Opedal, Arnfrid

1998 De glemte skipsgravene: makt og myter på Avaldsnes. Arkeologisk museum i Stavanger, Stavanger.

Oscarsson, Ulla

2010 De gåtfulle Överhogdalsbonaderna. Jamtli, Östersund.

Raknes Pedersen, Inger

1982 The Analyses of the Textiles from Evebø / Eide, Gloppen, Norway. I Textilsymposium Neumünster, Archäologische Textilfunde 6.5-8.5.1981, redigeret af Lise Bender Jørgensen og Klaus Tidow, s. 75-84. Textilmuseum Neumünster, Neumünster.

1983 The textiles from the Migration period grave at Evebø / Eide, Gloppen, Sogn og Fjordane, Norway. Studien zur Sachsenforschung 4:304-313.

1988 The Analysis of the Textiles from Blindheim, Giske. I Archaeological Textiles, Report from the 2nd NESAT Symposium 1.-4.V. 1984, redigeret af Lise Bender Jørgensen, Bente Magnus og Elisabeth Munksgaard, s. 116-125. Københavns Universitet, København.

Shetelig, Haakon.

1902 En plyndret baadgrav. Bergens Museums Aarbok 1902: Kapitel 8.

1903 Fragments of an old boat from Halsnø. Bergens Museums Aarbok 1903: Chapter 7: Notes from the Antiquarian Collection: 8-21.

1912 Vestlandske graver fra jernalderen, A/S John Griegs Boktrykkeri, Bergen.

Shetelig, Haakon og Anton Wilhelm Brøgger

1908 Fortegnelse over de til Bergens Museum i 1907 indkomne saker ældre end reformationen. Bergens Museums Aarbok 1908, No. 3.

Sørnes, Knut Arne

2012 Halsnøybåten frå romersk jernalder: historia frå funn til rekonstruert båt. Eige Forlag, John Grieg AS, Bergen.

Vedeler, Marianne

2019 Oseberg. De gåtefulle billedvevene. Spartacus forlag/Scandinavian Academic Press, Oslo. Von Holstein, Isabella

2012 A light stable isotope (C, N, H, O) approach to identifying movement of medieval textiles in North West Europe. Unpublished PhD thesis, University of York, York. 
Wincott Heckett, Elizabeth

1992 An Irish "Shaggy Pile" Fabric of the $16^{\text {th }}$ Century - an Insular Survival? I Archaeological Textiles in Northern Europe (Tidens Tand Nr. 5), redigert av Lise Bender Jørgensen og Elisabeth

Munksgaard, s. 158-168. Konservatorskolen, Det Kongelige Danske Kunstakademi, København. 